Review

\title{
Enzyme technology and biological remediation
}

\author{
C.G. Whiteley ${ }^{\mathrm{a}, *}$, D.-J. Lee ${ }^{\mathrm{b}}$ \\ ${ }^{\text {a }}$ Department of Biochemistry, Microbiology and Biotechnology, Rhodes University, Artillery Rd., P.O. Box 94, Grahamstown 6139, South Africa \\ ${ }^{\mathrm{b}}$ Department of Chemical Engineering, National Taiwan University, Taipei, Taiwan, ROC
}

Received 1 October 2004; received in revised form 30 September 2005; accepted 18 October 2005

\begin{abstract}
The heterogeneous complexity of sludges and wastewaters has created gross uncertainty and deviations in predictions of suitable models for their measurement. At the same time, it is becoming increasingly obvious that the current paradigms and ideologies are wrought with problems and limitations suggesting the need to move to a more consolidated analytical objective evaluation. Rapid developments in understanding activated sludge processes and wastewater remediation warrants exploitation of different strategies for studying their degradation.

It is time to replace subjective terms like sludge volume index (SVI), zone settling velocity (ZSV), filament index $\left(F_{\mathrm{I}}\right)$, fractal dimension $(D)$, flocculating ability, surface charge $(\zeta)$, degree of hydrophobicity, chemical oxygen demand (COD) with a mathematical one that can provide an absolute quantitative relationship for the properties of wastewater and/or a sludge floc. There are no current objective values that can be introduced to represent the plethora of biological remediation terminologies such as bioleaching, biosorption, bioaugmentation, biostimulation, biopulping, biodeterioration, biobleaching, bioaccumulation, biotransformation and bioattenuation.

Enzyme technology has been receiving increased attention and this review focuses on the latest developments on the enzymology of biological remediation. It discusses the present pitfalls with current strategies and suggests that sludge-floc parameters, such as internal structure and composition, sludge retention time, microbial ecology, nutrient concentration, dissolved oxygen and type of industrial wastewater, whether from an aerobic or anaerobic system, are replaced by quantitative kinetic terms $\left(K_{\mathrm{m}}, V_{\mathrm{max}}, K_{\mathrm{cat}}\right)$ associated with the enzymology of the sludge floc and/or wastewater.
\end{abstract}

(C) 2005 Elsevier Inc. All rights reserved.

Keywords: Aerobic; Anaerobic bioremediation; Enzymology

\section{Contents}

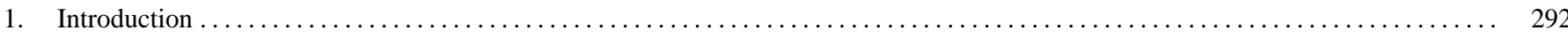

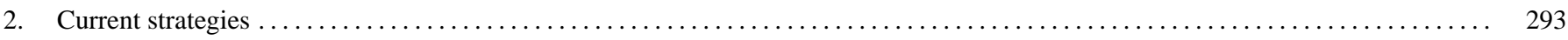

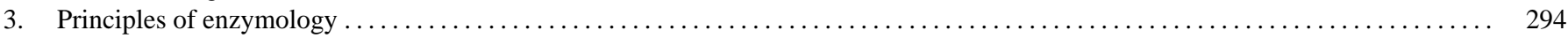

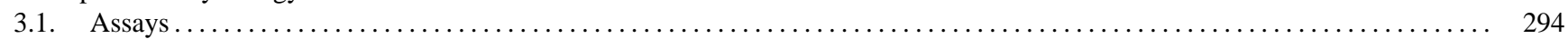

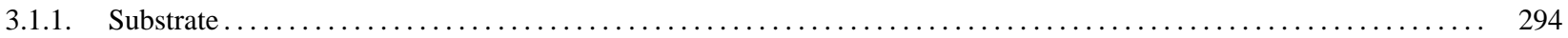

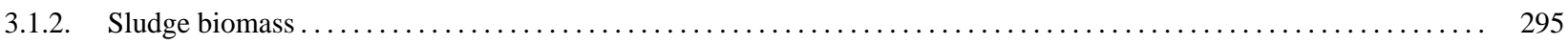

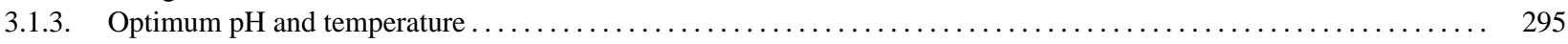

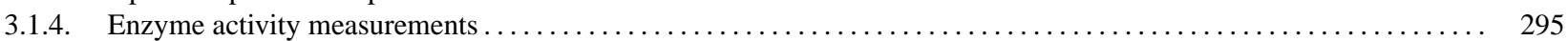

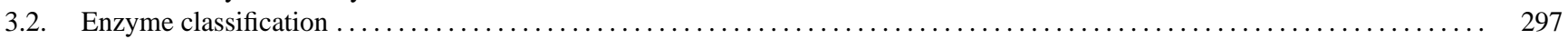

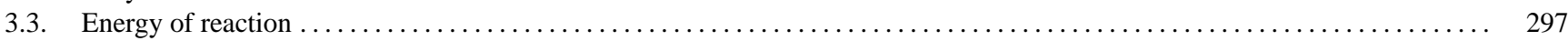

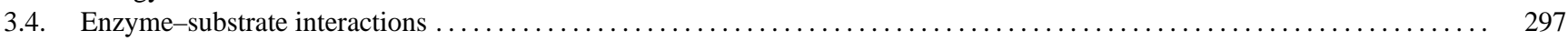

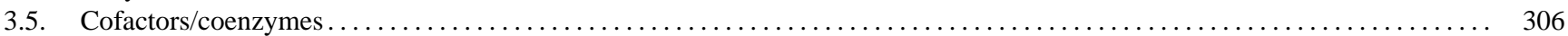

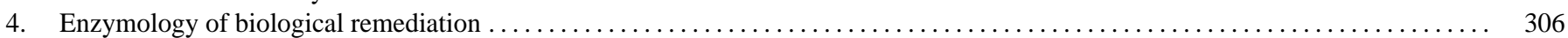

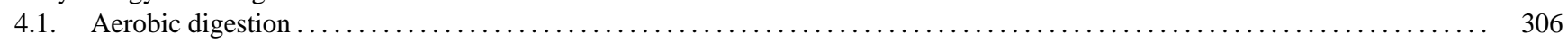

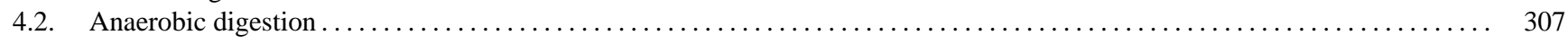

\footnotetext{
* Corresponding author. Tel. +27 46 6038085; fax: +27 466223984 .

E-mail address: c.whiteley@ru.ac.za (C.G. Whiteley).
} 


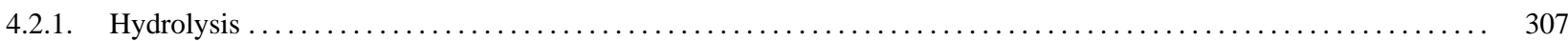

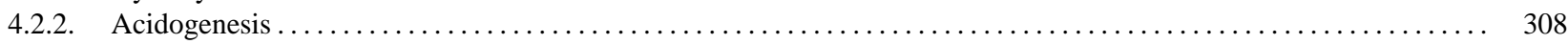

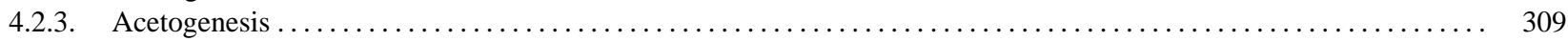

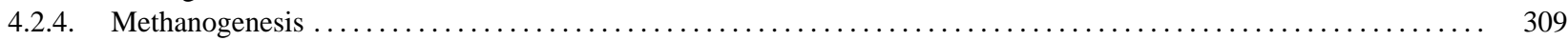

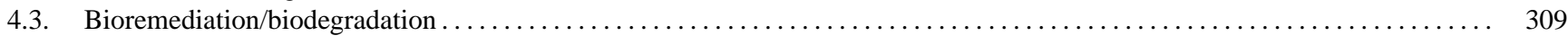

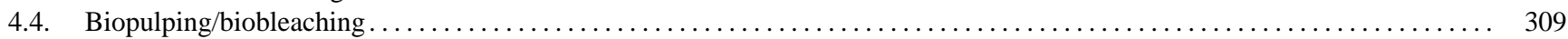

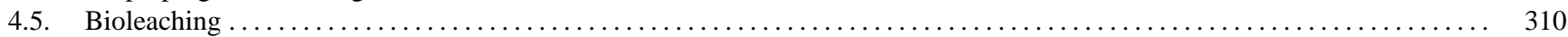

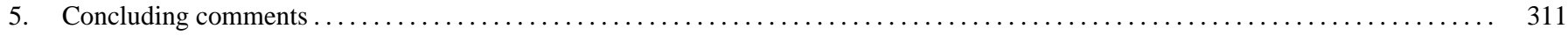

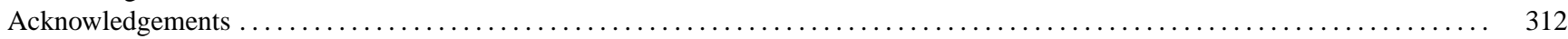

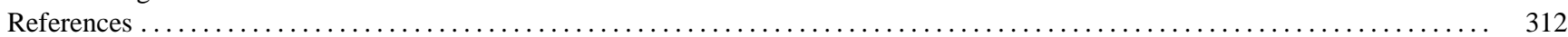

\section{Introduction}

With a necessity of improvement in biological remediation techniques, enzyme technology has been receiving increased attention. Previous researchers have used enzymes in activated sludge systems as indicators of specific microbial populations [1], measure of active biomass [2,3] and as indicators of processes such as chemical oxygen demand and phosphorous removal [4]. According to Aitken [5], enzymes were first proposed for the treatment of waste in the 1930s, but it was not until the 1970s that enzymes were used to target specific pollutants in waste. The rapid developments and associated increase in complexity of understanding activated sludge processes and wastewater remediation warrants exploitation of different strategies for their degradation. The heterogeneous complexity of sludge has created gross uncertainty and deviation in predictions of suitable models for its measurement. Even the predictive powers of mathematical models or generic algorithms are limited or handicapped by the input of subjective information. Throughout the following discussion, the emphasis will be on moving away from the current ideologies and accepted paradigms on sludge-floc measurements towards a more unified consolidated analytical objective system. Enzymology may be regarded as being at the interface between, on the one hand, biological discovery and protein engineering and environmental biotechnology on the other. Microorganisms can be genetically 'engineered' to express specific xenobiotic metabolising enzymes that would degrade even the most recalcitrant pollutants. The role of microorganisms, however, is wrought with problems. The accumulation in the environment of highly toxic pollutants only emphasises the fact that micro-organisms, by themselves, are insufficient to protect the biosphere from anthropogenic pollution. Furthermore, although microorganisms may enhance the transformation of the pollutants making them more effective agents of bioremediation and biodegradation it leads to the generation of a considerable amount of biomass. Any biostimulation approach has limited potential since individual bacteria, that are capable of remediating a given pollutant, maybe inhibited by the presence of other pollutants. A limiting factor in the bioremediation of polluted contaminated sites is the very slow rate of degradation that limits, further, the practicality of using bacteria during these processes.

Characteristics of primary and secondary sludge are quite different in terms of nutrients and pollutants. While secondary sludge has higher nitrogen and phosphorus contents that are important pre-requisites for agricultural use, primary sludge tends to be more 'polluted' with heavy metals and organic chem- icals. The latter, which include polychlorinated hydrocarbons (PCBs), polycyclic aromatic hydrocarbons (PAHs), benzene, toluene, ethylbenzene, xylene (BTEX), petrochemicals, agricultural chemicals (biopesticides) and dyes, tend to have low water solubility and lipophilic properties and consequently are associated with the sludge organic particulate matter. This poses further problems if the dried sludge is applied to farmlands as these recalcitrant pollutants may enter the food chain and water table. Wastewater sludge can be viewed as a two-phase system - a solid network of hydrophilic polymeric materials enclosing a liquid (water) within. It is possible to enzymatically attack this complex bioreactor in order to recover valuable resources, remove toxic materials and recover the water. Bioprocesses that convert one material into another using biological agents (e.g., living microbes or enzymes) involve biological remediation techniques that generally fall under the umbrellas of either aerobic or anaerobic digestion. Furthermore, within these two systems the activated wastewater sludge processes may be categorized into several divisions (Fig. 1). Intrinsic bioremediation is the removal, transformation or detoxification of any contaminating pollutant from the environment to a less toxic form by any natural process. Alternatively, any attempt to manipulate contaminated environmental areas by the addition of stimulants or additives (biostimulation) or the addition of special specific biochemicals or microorganisms (bioaugmentation) can be classified as accelerated bioremediation. Biostimulation and bioaugmentation are often used in conjunction with one another-one to supply the nutrients to enhance the microbial growth and the other to enhance environmental hazard waste.

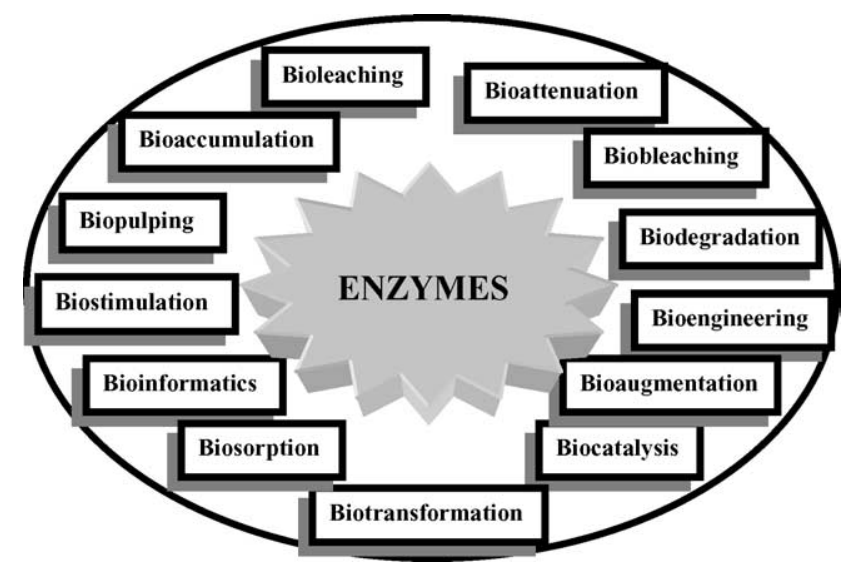

Fig. 1. Overview of the enzymology of biological remediation. 
Biodegradation, mineralization, bioremediation, biodeterioration, biotransformation, biosorption and bioaccumulation are overlapping terms with minor subtle differences. Biodegradation is the general term used for all biological breakdown of chemical compounds and complete biodegradation leads to mineralization. Biotransformation is a step in the biochemical pathway which leads to the conversion of a molecule into a less toxic product. Biodeterioration is the breakdown of economically useful compounds but often the term has been used to refer to the degradation of normally resistant substances such as plastics, cosmetics, paint, wood products and metals [6]. Biosorption is the process by which metals are removed from aqueous solution by complexing to either living or dead biomass through functional sites that include: carboxyl, imidazole, sulphydryl, amino, phosphate, sulphate, thioether, phenol, carbonyl, amide and hydroxyl moieties $[7,8]$. Bioaccumulation includes all processes responsible for the uptake of metal ions by living cells and includes enzymatic degradation, biosorptive mechanisms, together with intracellular accumulation and bioprecipitation [9].

It is an intention of this review to propose a strategy for the specific enzymology of all of the biological remediation processes, whether in aerobic or anaerobic systems, and to suggest a novel enzyme-floc model that will describe these mechanisms. The paper is divided into three. The first part critically evaluates the current strategies for sludge floc measurements; the second part describes the fundamental principles of enzymology while part three identifies significant roles that particular enzymes play in bioremediation.

\section{Current strategies}

The overall performance of any wastewater treatment, whether in activated aerobic sludge processes or anaerobic digesters, is controlled by the internal structure, composition and microbial ecology of the floc. Furthermore, the nature of activated sludge is dependent on many process variables, such as nutrient concentration, sludge retention time (SRT), reactor configuration, dissolved oxygen, type of industrial wastewater and consequently its study and its management is a complex and sometimes conflicting task [10]. Sludge flocs are characterized by being fragile, easily compressible, porous and permeable to fluids, irregular in shape with a networked multi-level structure $[11,12]$. It is safe to say that they are microreactors, capable of absorbing and decomposing pollutants yet grossly complex and differentiated by their own morphology and both physical and chemical attributes. It is not surprising, when it comes to any indepth study of the activated waste flocs, to be faced with conflicting answers to the numerous questions. In addition, the current accepted parameters and properties used to measure and analyse activated sludge flocs and/or biofilms are redundant and wrought with problems and limitations. It is time to replace subjective terms like sludge volume index (SVI), zone settling velocity $(\mathrm{ZSV})$, filament index $\left(F_{\mathrm{I}}\right)$, fractal dimension $\left(D_{\mathrm{f}}\right)$, flocculating ability, degree of hydrophobicity, surface charge, volatile suspended solids (VSS), oxygen and nutrient utilization rates and chemical oxygen demand (COD) with an objective, finite, mathematical term that can provide an absolute quantitative relationship for a sludge floc.

Settleability, compresseability and dewaterability of activated sludge are crucial parameters from which to monitor overall performances and efficiency of the treatment process. There are grave difficulties, however, in determining SVI and ZSV as well as giving support that they are non-specific measures of activated sludge characteristics [13]. Even attempts to correlate the SVI with the ZSV is questionable despite support from the literature to the contrary [14]. Further complications arise when it comes to comparing sludges from different sources since different factors (floc size, composition, presence of filaments) cause variations in settling properties. How is it possible, or even remotely feasible, to compare the SVI and the ZSV from a small measuring cylinder with that of a full-scale settling tank?

Fractal index is often used to describe the geometric characteristics of the multilevelled floc structure $[15,16]$. For linear, planar and three-dimensionally compact objects the exponent fractal dimension $(D)$, determined from the slope of the double log plot (Eqs. (1) and (2)), will take on values of 1, 2 and 3 respectively.

$M \propto R^{D}$

$\log M=D \log R$

$M$ is the mass of the floc, $D$ the fractal number and $R$ is the floc radius. [17]. Since floc aggregates are not circular or spherical the longest dimension, $l$, may be used in place of $R$ and [Area] (as floc area) in place of $M ; D_{2}$ would then represent the fractal dimension in two dimensions. Filament index $\left(F_{\mathrm{I}}\right)$ measures the amount of filamentous bacteria and is usually rated on a scale of $1-5$, with an index of 1 that corresponds to no filaments and an index of 5 to excess filaments. The variation in both these parameters with the textural variety in sludge wastes make it difficult, if not impossible, to calculate finite values. The issue is exacerbated further by researchers attempting to assign definitive structures to complex aggregates of activated sludge that possess a multi-level conglomerate of primary particles, microflocs and porous flocs [16]. The problem with filament index and its overall use in a floc dimensional study is that it is extremely difficult to quantify accurately for not only would its length be important but its morphology and surface properties as well. How is it possible to compare the characteristics of two, or more, different activated waste flocs from two different sites when one has a very low, and the other a high filament index? In one case, the flocs make a particle-to-particle contact resulting in a compacted, small size, high density "floc-floc" aggregate with excellent compresseability and settleability. In the other, a filament-to-filament or rather floc-to-filament, large, loose, low density aggregate forms with large voids between them and consequently poor compresseability and settleability.

The method for determination of flocculating ability of activated sludge flocs is based upon the ability for flocs to reflocculate after they have been subjected to fracture. Depending on the differences in physico-chemical properties of sludge flocs will reflect the different abilities of different flocs to both deflocculate and reflocculate. Can one really compare different sludges 
on a quantitative basis? Are there elements in the bulk water that, once released during deflocculation, prevent any kind of reflocculation? In simple terms, it is obviously clear that problems, in sludge floc studies are manifested when using flocculating ability.

Sludge floc surface charge, zeta potentials $(\zeta)$, hydrophobicity and viscosity have also been measured in their capacity for monitoring sludge characteristic properties. The extent of interaction between particles depends on both the thickness of the electrical layers and the surface potential. If any polyvalent counterions are present the electrostatic repulsion is reduced and the floc constituents more easily adhere to each other. Once again, however, the findings and suggestions are tantamount to speculation and should be approached with caution [18]. The importance of surface charge in sludge flocs can only be relevant in filamentous free sludges - a scenario that is hardly practical or feasible - otherwise the filaments themselves would act as a physical bridge between the flocs [19]. Surface charge is affected by surface area of the floc and with the ubiquitous presence of filaments there would be an increase in surface area leading to false measurements. Furthermore, as the sludge flocs settle the assumed high negative surface charge on the flocs would create a microrepulsion leading to a more expanded state and consequently a fuzzy area in the correlation of surface charge to activated sludge properties. Even the rate of floc settling would be slower leading to erroneous results. All of the literature reports pertaining to the role of hydrophobicity on floc properties originate from homogeneous suspensions and not from heterogeneous aggregates. Consequently, it is unwise to use this parameter for any meaningful determination of sludge characteristic. Finally, inconclusive findings and a lack of literature for the role of viscosity on the rheological properties of activated sludge and its compresseability and settleability excuse any further discussion.

Extracellular polymeric substances (EPS), produced from bacterial cellular metabolism, cell autolysis and the wastewater itself, cement sludge components together and consequently any hydrolysis of the EPS would lead to significant changes in sludge structure [20]. EPS play a crucial role in the flocculation, settling and dewatering of activated sludge [21-24] and since the quantity and composition of EPS for a given sludge are strongly dependent on the extraction methods it suggests, without any standard extraction protocol in place, that any comparative interpretation of published results would be extremely difficult. EPS are highly charged and so absorb water to reduce any differences in osmotic pressure between the aggregates and surrounding liquid $[18,25]$ and as a result the EPS would tend to become more gel-like rather than rigid particles. This makes current evaluations of sludge characteristics difficult to resolve. The precise role of polymers with respect to sludge properties is, therefore, very complicated and it would be grossly in error to use any standard protocol for EPS as a finite quantitative measurement.

The development of any mathematical model with a differential algebraic equation to describe a biological process related to wastewater activated sludge originates as a numerical simulation aimed at predicting the system behaviour or functional optimization. Nevertheless, in order to derive these algorithms various component quantities and their respective interactions must be established, model parameters calibrated, initial and final conditions understood and a final validation of the model undertaken using actual experimental data. The key to any model is to select relevant quantities and processes and then to describe them by means of logical equations, rules, probabilities, transitions. Fluid dynamics, convective and diffusive transport, mechanical loads, biochemical reactions, metabolic entitities, thermodynamics, competitive co-existence of species reflect a vast array of variable components This myriad of challenging protocols required for an activated sludge floc and/or biofilm puts the viability of using such models near the bottom of the success ladder. It would be a gross improbability to design a single computer algorithm that would take into account all of the parameters and scenarios mentioned above and treat them, not as individual components but, as an integrated factorial matrix. It is 'easy' to design a model for any process or processes but it is the reality and viability of the process to hold true against actual experimental data that makes it acceptable.

It is time to move back a step and examine, at a cellular and genomic level, the biochemical and biotechnological properties, structure, formation and decomposition of activated sludge flocs. All of the parameters in the foregoing discussion, whether they be statistically correlated or not, must be consolidated into a single objective, finite, mathematical term that can provide an absolute quantitative relationship for a sludge floc. Even novel analytical techniques such as confocal laser scanning microscopy (CLSM), scanning and transmission electron microscopy (SEM, TEM), atomic force microscopy (AFM) and small angle laser light scattering (SALS) suffer from a similar fate as their 'modus operandi' is based upon parameters already discussed.

\section{Principles of enzymology}

\subsection{Assays}

To analyse the properties of an enzyme in sludge biomass a valid assay needs to be developed with a specific substrate and using conditions that produce maximum activity. So questions to ask are: (1) How much substrate? (2) How much sludge biomass (enzyme)? (3) What are the optimal $\mathrm{pH}$ and temperature? (4) How is enzyme activity measured?

\subsubsection{Substrate}

To find the amount of substrate necessary for an enzyme assay one must measure either the disappearance in substrate during the enzyme catalyzed reaction or the appearance of product. Though the assay may be more sensitive if appearance of product is measured, since one would start the assay with no product at all, it would be necessary to ensure that, in a biologically active environment the product is not used in any way by any alternative systems. Also, it would be necessary to establish that, in the absence of the enzyme under investigation, the substrate(s) do not react to produce any kind of product that may interfere with the assay protocol. Whichever way the evaluation method must be quantitative and give results in amounts of micromole 

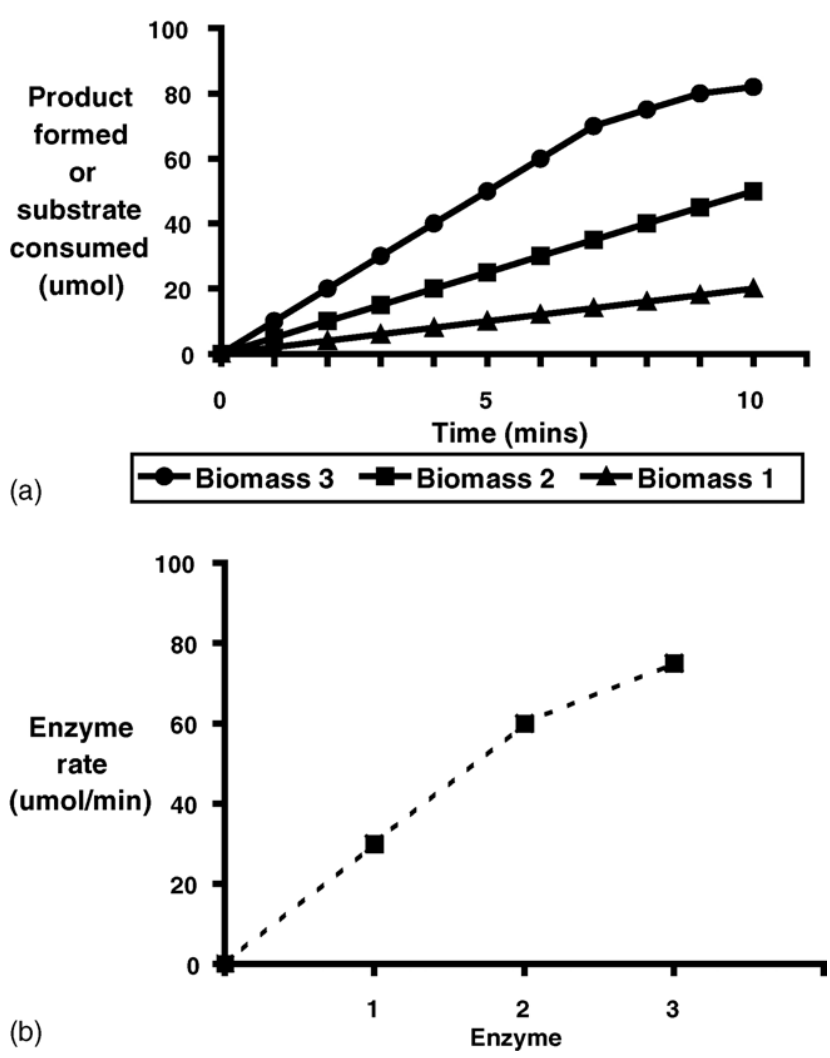

Fig. 2. Enzymatic progress curves: (a) amount of product per unit time per enzyme concentration and (b) rate of enzyme reaction with respect to enzyme concentration.

product formed or substrate consumed during a measured period of reaction time, usually minutes. This is called the enzyme catalyzed rate or enzyme activity.

\subsubsection{Sludge biomass}

In order to establish the minimum amount of activated sludge/biomass that will be necessary for the particular enzyme assay under study it is necessary to set up, what are called, progress curves. This is in order to find conditions from which there is a linear response to an enzyme assay with respect to its substrate (or product) and time.

Sludge biomasses 1 and 2 (Fig. 2a and b) produce linear responses for $10 \mathrm{~min}$ of reaction time used, while at sludge biomass 3 , the amount of substrate (or product) falls off after 7 min and consequently using either 1 or 2 sludge biomass amounts would give a reliable valid assay. With sludge biomass 3 some other influence is present to consume substrate or limit the formation of product. When the amount of product produced (or substrate consumed) in $10 \mathrm{~min}$ is used to calculate the enzyme rate, a plot can be made to show what minimum amount of sludge biomass is valid for the assay.

\subsubsection{Optimum $\mathrm{pH}$ and temperature}

After the valid amount of sludge biomass (enzyme) to use is found, it is necessary to optimize the $\mathrm{pH}$ and temperature. This is done by resuspending the sludge biomass in buffers of different
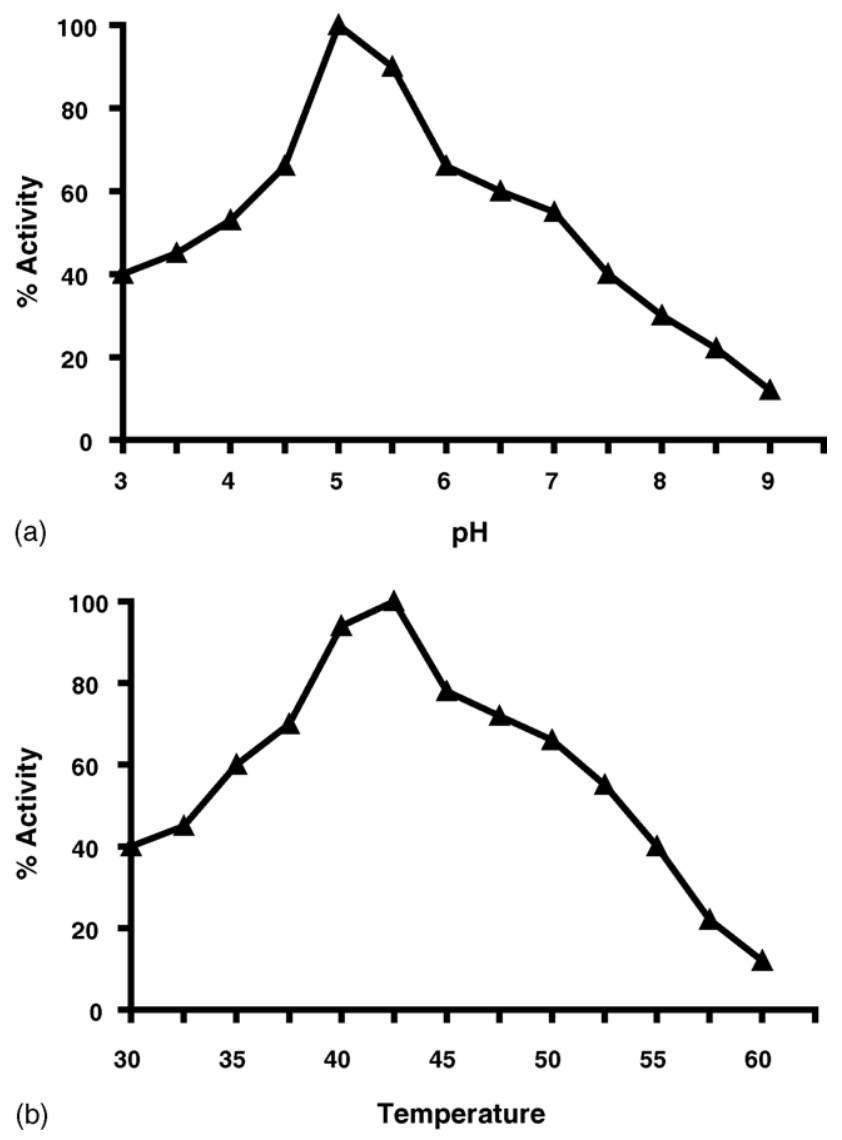

Fig. 3. Enzyme activity with respect to (a) $\mathrm{pH}$ and (b) temperature.

$\mathrm{pH}$ (or temperature), calculating the enzyme activity rates at each $\mathrm{pH}$ (or temperature) and then plotting the respective curves (Fig. 3a and b).

Amino acids constitute the active catalytic region of every enzyme and the various side chains of the basic and/or acidic amino acids can exist in either of two forms-ionized or protonated. Optimum $\mathrm{pH}$ for an enzyme lies somewhere between the $\mathrm{p} K_{\mathrm{a}}$ values of the two (or more) catalytic amino acids. Consider the catalytic mechanism of a particular protease to be controlled by two glutamic acid residues-one ionized and the other protonated. Any $\mathrm{pH}$ lower than the optimum would protonate the ionized residue while any $\mathrm{pH}$ higher than the optimum would ionize the protonated residue leading to decreased activity.

Most enzymes have an optimum temperature, which may be related to the type of organism from which the enzyme was isolated. Some organisms grow well near room temperature and so their enzymes are most active at a temperature around $30-40^{\circ} \mathrm{C}$. At low temperatures, all the molecules in the solution slow down and so does the enzyme catalyzed reaction while at high temperatures, the thermal movement of the molecules become too great for the enzyme to hold its shape or conformation and so it begins to denature and lose its activity.

\subsubsection{Enzyme activity measurements}

According to the Beer Law (Eq. (3)) the absorbance, or fluorescence or whatever optical parameter is being used, is directly 
Table 1

Reagents, procedures and sensitivities of different protein assays

\begin{tabular}{|c|c|c|c|}
\hline $\begin{array}{l}\text { Assay; Ref.; Sensitivity; } \\
\text { Accuracy }\end{array}$ & Interference; Principle & Reagents & Procedure \\
\hline Biuret [26] 1-10 mg Good & $\begin{array}{l}\text { Ammonium salts; Colour } \\
\text { between } \mathrm{Cu}^{+} \text {and peptide } \\
\text { bond }\end{array}$ & $\begin{array}{l}\text { Sodium potassium tartrate } \\
{[2.25 \mathrm{~g}] \mathrm{CuSO}_{4}[0.75 \mathrm{~g}] \mathrm{KI}} \\
{[1.25 \mathrm{~g}] \text { in } 100 \mathrm{ml} 0.2 \mathrm{M}} \\
\mathrm{NaOH} \text { and diluted to } 250 \mathrm{ml}\end{array}$ & $\begin{array}{l}\text { Biuret reagent } \\
(9.0 \mathrm{ml})+\text { sample }(1.0 \mathrm{ml}) \\
\text { mixed, allowed to stand } \\
(20 \mathrm{~min}) ; \text { absorbance read } \\
\text { at } 550 \mathrm{~nm}\end{array}$ \\
\hline $\begin{array}{l}\text { Folin-Lowry }[26,160] \\
\text { 20-300 } \mu \mathrm{g} \text { Good }\end{array}$ & $\begin{array}{l}\text { Strong acids, Ammonium } \\
\text { salts; Colour between } \mathrm{Cu}^{+} \\
\text {and aromatic amino acids and } \\
\text { phosphomolybdate }\end{array}$ & $\begin{array}{l}\mathrm{Na}_{2} \mathrm{CO}_{3}(2 \%) \text { in } 0.1 \mathrm{M} \\
\mathrm{NaOH}(49 \mathrm{ml}) ; \mathrm{CuSO}_{4}(1 \%) ; \\
\mathrm{KOOCCH}(\mathrm{OH}) \mathrm{CH}(\mathrm{OH}) \mathrm{COONa} \\
(2 \%, 0.5 \mathrm{ml})\end{array}$ & $\begin{array}{l}\text { Lowry reagent }(1.0 \mathrm{ml}) ; \\
\text { sample }(100 \mu \mathrm{l}) \text { mixed, } \\
\text { allowed to stand }(30 \mathrm{~min}), \\
\text { Folin reagent }(100 \mu 1,1 \mathrm{M}) \\
\text { added, incubated }(30 \mathrm{~min}), \\
\text { absorbance read at } 595 \mathrm{~nm}\end{array}$ \\
\hline $\begin{array}{l}\text { Bradford [26,161] } \\
1-100 \mu \mathrm{g} \text { Good }\end{array}$ & $\begin{array}{l}\text { Absorbance maximum for an } \\
\text { acidic solution of Coomassie } \\
\text { Brilliant Blue G- } 250 \text { shifts } \\
\text { from } 465 \text { to } 595 \mathrm{~nm} \text { when } \\
\text { binding to protein occurs }\end{array}$ & $\begin{array}{l}\text { Bradford reagent: Dissolve } \\
100 \mathrm{mg} \text { Coomassie Brilliant } \\
\text { Blue G-250 in } 50 \mathrm{ml} 95 \% \\
\text { ethanol, add } 100 \mathrm{ml} 85 \% \\
\text { (w/v) phosphoric acid. Dilute } \\
\text { to } 11 \text {, filter }\end{array}$ & $\begin{array}{l}\text { Sample }(5 \mu \mathrm{l}) \text { and } \\
\text { Bradford reagent }(250 \mu \mathrm{l}) \\
\text { incubated and absorbance } \\
\text { read at } 595 \mathrm{~nm}\end{array}$ \\
\hline $\begin{array}{l}\text { Bicinchoninic [BCA] [26] } \\
\quad 0.2-50 \mu \mathrm{g} \text { Good }\end{array}$ & $\begin{array}{l}\text { Strong acids, Ammonium } \\
\text { salts; BCA reduces divalent } \\
\text { copper to the mono-valent ion } \\
\text { under alkali conditions. A } \\
\text { molybdenum/tungsten blue } \\
\text { product is produced }\end{array}$ & $\begin{array}{l}\text { Reagent A: } 1 \text { gm sodium } \\
\text { bicinchoninate }(\mathrm{BCA}), 2 \mathrm{gm} \\
\mathrm{Na}_{2} \mathrm{CO}_{3}, 0.16 \text { gm sodium } \\
\text { tartrate, } 0.4 \mathrm{gm} \mathrm{NaOH} \text {, and } \\
0.95 \mathrm{gm} \mathrm{NaHCO}_{3} \text {, in } 100 \mathrm{ml} \\
\text { distilled water. Adjust the } \mathrm{pH} \\
\text { to } 11.25 \text { with } 10 \mathrm{M} \mathrm{NaOH} \\
\text { Reagent B: } 0.4 \text { gm cupric } \\
\text { sulfate }(5 \times \text { hydrated) in } \\
10 \text { ml water. } \\
\text { Standard working solution } \\
\text { (SWR): Mix } 100 \text { volumes } \\
\text { reagent A with } 2 \text { volumes } \\
\text { reagent B }\end{array}$ & $\begin{array}{l}\text { Prepare samples containing } \\
0.2-50 \mu \mathrm{g} \text { protein in } 20 \mu \mathrm{l} \text {. } \\
\text { Add } 1 \mathrm{ml} \mathrm{SWR} \text { to each } \\
\text { sample and mix. Incubate } \\
30 \text { min at } 60^{\circ}\end{array}$ \\
\hline
\end{tabular}

proportional to the concentration of the reagent.

$A=\varepsilon l c$

where $A$ is the absorbance, $\varepsilon$ the extinction coefficient, $l$ the path length and $c$ is the concentration usually in $\mu \mathrm{mol} \mathrm{ml}^{-1}$. In the case of enzymes, this concentration is per unit time and is the same as activity, i.e. $\mu \mathrm{mol} \mathrm{ml} \mathrm{m}^{-1} \mathrm{~min}^{-1}$. Consequently, if one knows the extinction coefficient of a substance at a particular wavelength and one is measuring the change in optical parameter over time it is possible to determine the activity $\left(v_{1}\right)$ of the enzyme (Eq. (4)):

$v_{1}=\Delta A \frac{V}{\varepsilon t v}$

where $\Delta A$ is the change in absorbance, $V$ the total volume in the assay mixture, $\varepsilon$ the extinction coefficient in $\mathrm{ml} \mu \mathrm{mol}^{-1}, t$ the time in min and $v$ is the volume of the sample.

The extinction coefficient for the substance under investigation can be found from the slope of a linear plot, usually by linear regression, between the absorbance and several concentrations of pure substance. For substances that do not absorb strongly they are usually reacted with a dye to produce a colour that is measured at some specific wavelength in the visible spectrum. The units of enzyme activity per mass of protein is referred to as the specific activity and the amount of protein in the biomass may be determined in several ways depending on the sensitivity range of the protein. (Table 1) [26].

The kinetics of simple enzyme catalysed reactions was first characterised in 1912 by two biochemists Michaelis and Menten as they derived the hyperbolic equation:

$v_{1}=\frac{V_{\max }[S]}{K_{\mathrm{m}}+[S]}$

where $v_{1}$ is the rate of the enzyme catalysed reaction, $[S]$ the concentration of substrate, $K_{\mathrm{m}}$ the Michaelis-Menten constant and $V_{\max }$ is the maximum reaction rate. It can quickly be established that $K_{\mathrm{m}}$ is also equal to the substrate concentration that would give $50 \% V_{\max }$. At low substrate concentrations, the rate of an enzymatic reaction is of first-order and is directly proportional to substrate concentration $(v=k[S])$ (Fig. 4, point a) while at high substrate concentration the rate becomes independent of substrate concentration, is represented by zero order kinetics $\left(v=V_{\max }\right)$ (Fig. 4, point b) and almost all of the enzyme molecules are bound to substrate. To avoid using this curvilinear plot Lineweaver and Burk [27] introduced an analysis of enzyme kinetics by a straight line double reciprocal plot of $1 / v_{1}$ against $1 /[S]$ (Fig. 4, inset) with a slope of $K_{\mathrm{m}} / V_{\max }$ and an intercept on 


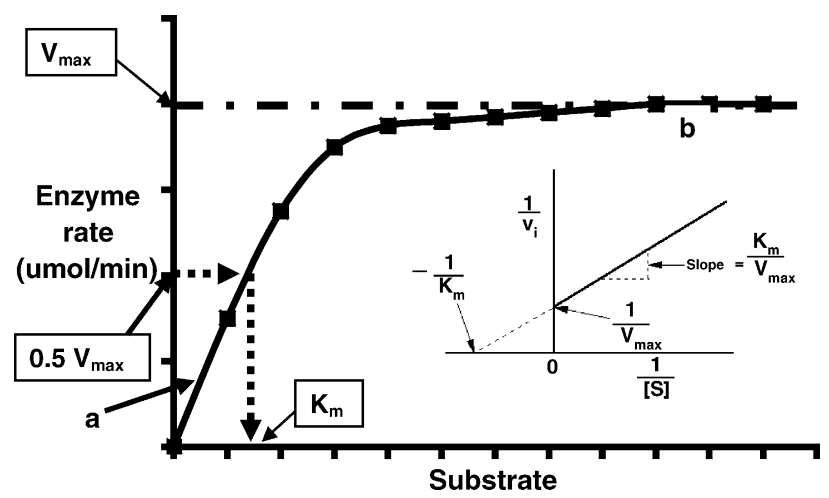

Fig. 4. A typical Michaelis-Menten curve representing change in velocity of an enzyme catalysed reaction with respect to substrate concentration (Inset: Lineweaver-Burke linear relationship).

the ordinate at $1 / V_{\max }$, from the following relationship.

$\frac{1}{v_{1}}=\left\{\left[\frac{K_{\mathrm{m}}}{V_{\max }}\right]\left[\frac{1}{S}\right]\right\}+\frac{1}{V_{\max }}$

Another term that is often used is $K_{\text {cat }}$. This is the catalytic formation of product by an enzyme and is the time required for an enzyme to 'turnover' a substrate molecule.

\subsection{Enzyme classification}

Enzymes are grouped into six functional classes by the Enzyme Commission of the International Union of Biochemists $[28,29]$ assigning each enzyme a unique four-digit number. The first describes the enzyme class, the second to the class bond of the substrate, the third to a sub-class or functional group of the substrate and the fourth to the actual molecule. It is the intention of this review not to present a detailed account of all of these enzymes but to report on those that are associated with biological remediation (Table 2).

\subsection{Energy of reaction}

Enzymes are biological catalysts responsible for supporting almost every type of chemical reaction. They are physiologically

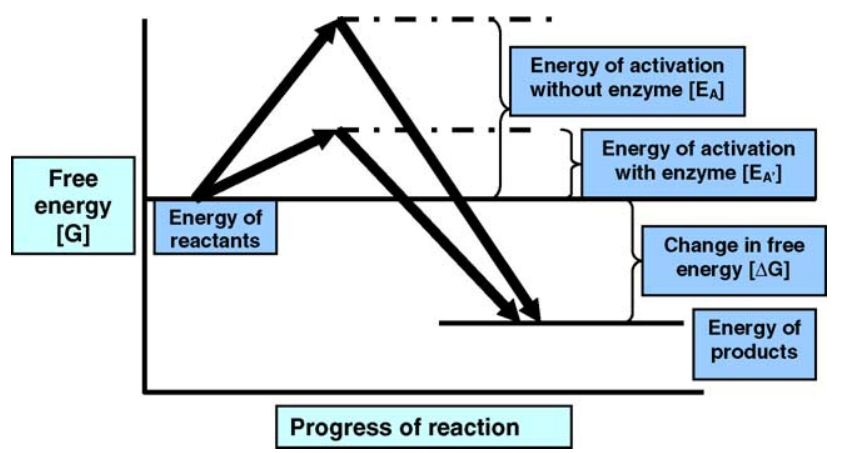

Fig. 5. Energy of reactants and products and activation energy with, and without, an enzyme.

important because they speed up, by at least 1000-fold, the rates of reactions by decreasing the amount of energy required to form a complex of reactants, known as the transition state complex, that is competent to produce reaction products. The free energy required to form an activated complex is much lower in the catalyzed reaction and consequently at any instant a greater proportion of the molecules in the population can achieve the transition state. The result is that the reaction rate is increased (Fig. 5).

\subsection{Enzyme-substrate interactions}

Enzymes interact with their specific substrate to form an enzyme-substrate complex [ES] by either a 'Lock-and-Key' or 'Induced Fit' model (Fig. 6) which then passes to a transition state $\left[\mathrm{ES}^{*}\right]$ and eventually to an EP complex which dissociates into product and free enzyme.

$\mathrm{E}+\mathrm{S} \leftrightarrow \mathrm{ES} \leftrightarrow \mathrm{ES}^{*} \leftrightarrow \mathrm{EP} \leftrightarrow \mathrm{E}+\mathrm{P}$

In the 'Lock-and-Key' model, the active site of the enzyme is complementary in shape to that of the substrate. With the, more favoured, 'Induced Fit' model, however, an initial weak interaction between enzyme and substrate rapidly induces conformational changes in the enzyme thereby strengthening the binding and bringing catalytic sites and scissile substrate bonds close together. Such catalysis takes place at the active site, within

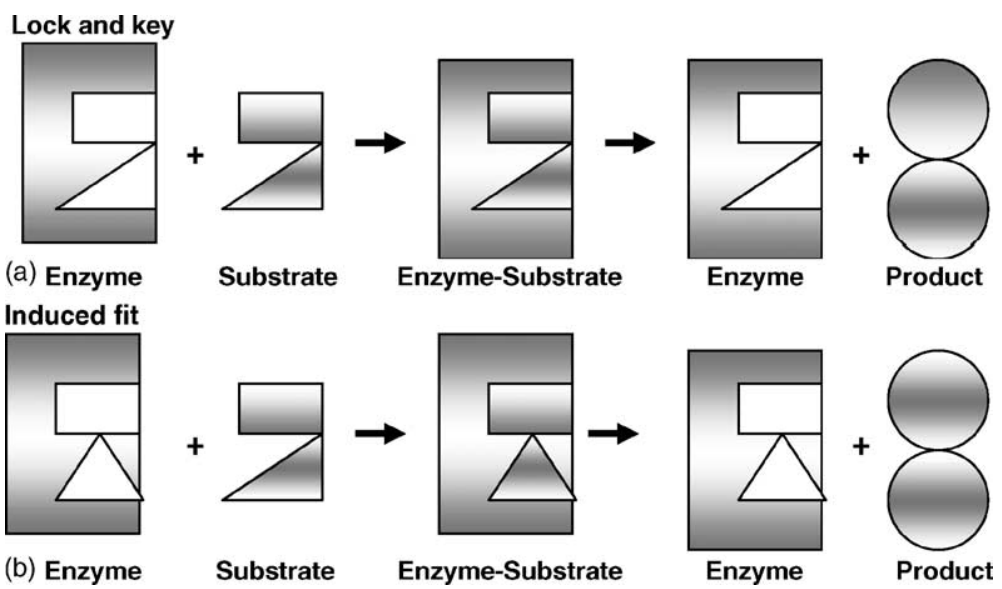

Fig. 6. Enzyme-substrate complex with (a) Lock-and-Key and (b) Induced Fit model. 
Reagents, reactions and classification of enzymes associated with biological remediation

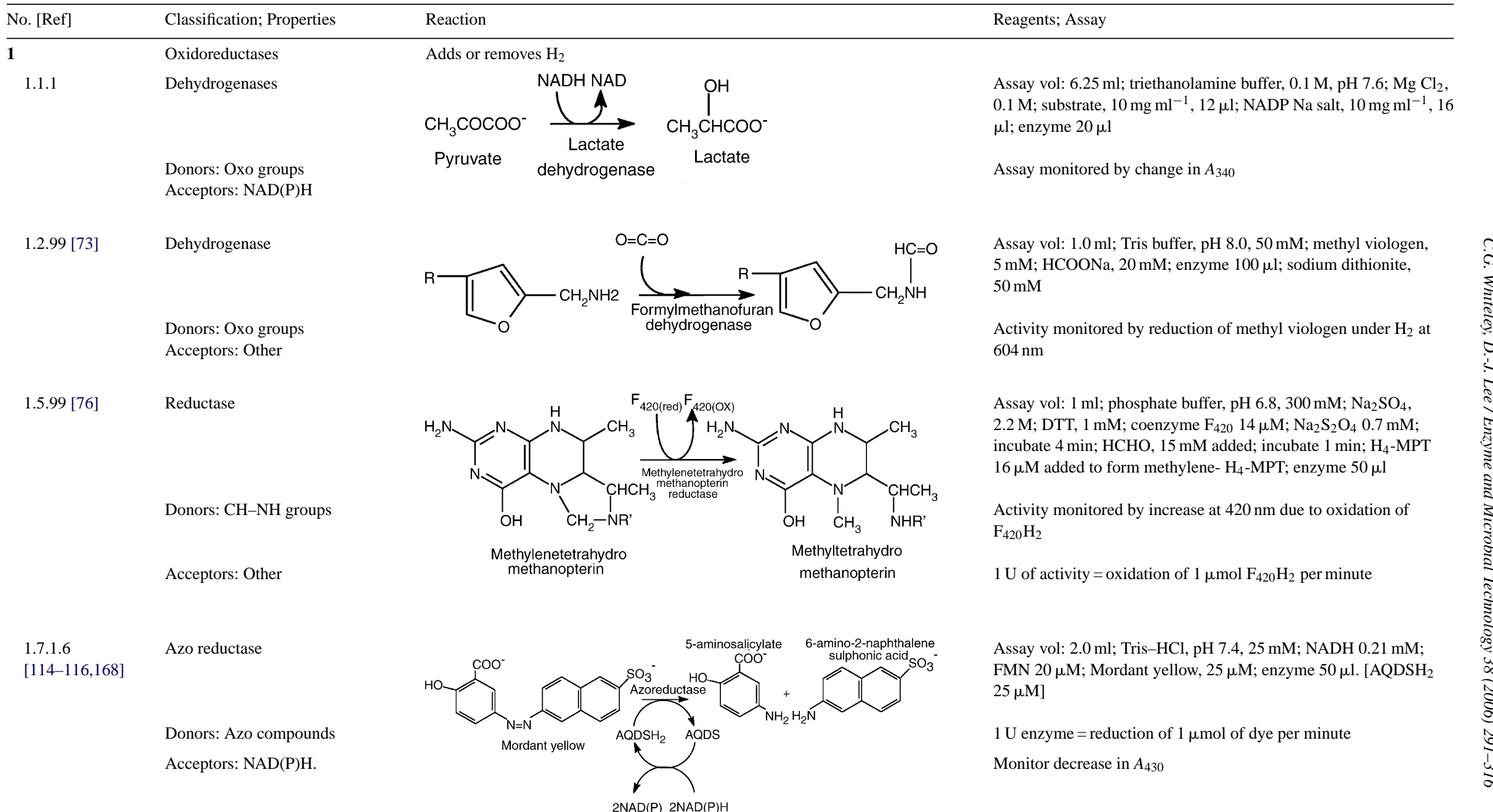

\subsubsection{2 \\ Nitrite reductase}

1.7.99.3

[148-152]
Donors: Nitro compounds

Acceptors: cytochrome or copper

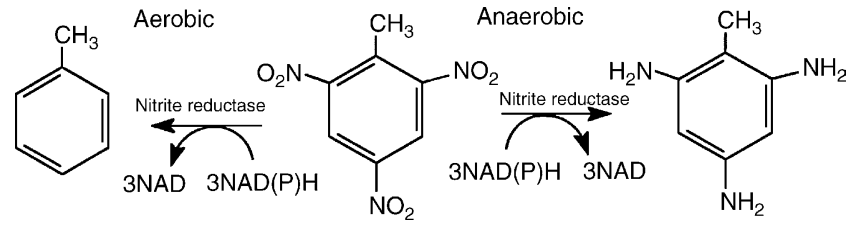

Assay vol: $1.0 \mathrm{ml}$; phosphate buffer, $\mathrm{pH} 7.0,50 \mathrm{mM}$; NADPH

$0.2 \mathrm{mM}$; TNT $0.1 \mathrm{mM}$,; enzyme $50 \mu \mathrm{l}$. Nitrite monitored at $540 \mathrm{~nm}$. Sample $600 \mu \mathrm{l}$; PMS $10 \mathrm{mM}, 1.5 \mu$ l; sulphanilamide, $1 \%$ in $0.68 \mathrm{M}$ $\mathrm{HCl}, 200 \mu \mathrm{l} ; \mathrm{N}$-(naphthyl) ethylenediamine, $1 \%, 40 \mu \mathrm{l}$

$1 \mathrm{U}$ activity $=$ consumption of $1 \mu \mathrm{mol} \mathrm{NADPH}$ per minute 
Donors: sulphur groups Acceptors: NAD(P)H

1.10.3.2

Oxidase

[102]

Donors: Diphenols Acceptors: $\mathrm{O}_{2}$

Acceptors: Peroxide

1.12 [169] Hydrogenases

Donor: $\mathrm{H}_{2}$

Acceptor: Fe-S protein

1.13.11.1 Dioxygenase

1.13.11.2 Dioxygenase

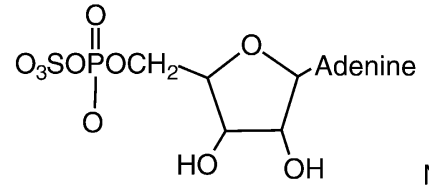

APS reductase $\mathrm{SO}_{3}^{-}+\mathrm{AMP}$ $\mathrm{NAD}(\mathrm{P}) \mathrm{H} \quad \mathrm{NAD}(\mathrm{P})$

Adenosine 5-phosphosulphate [APS]
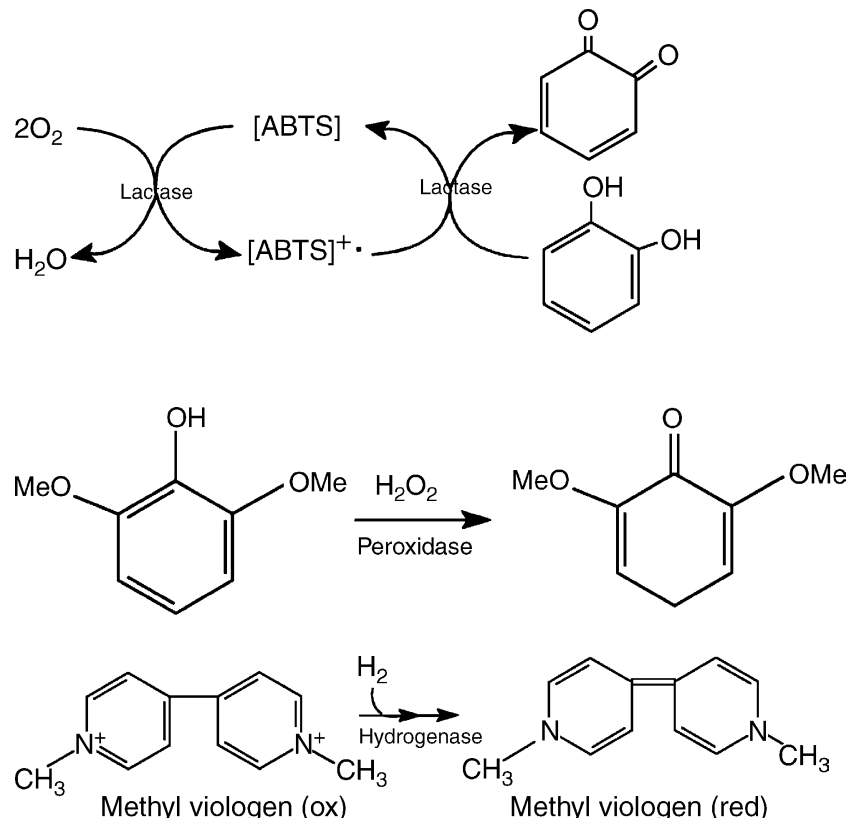

ortho-cleavage<smiles>Oc1ccccc1O</smiles>

Catechol

meta-cleavage

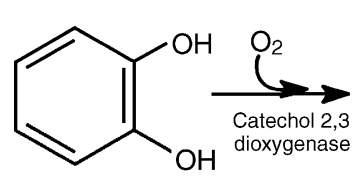

Catechol

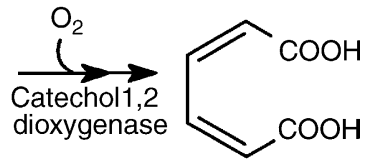

Muconate

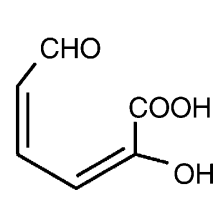

Hydroxymuconic
Assay vol: $1 \mathrm{ml}$; Tris- $\mathrm{HCl}$, $\mathrm{pH} 8.0,50 \mathrm{mM}$; AMP $2 \mathrm{mM}$; $\mathrm{K}_{3} \mathrm{Fe}(\mathrm{CN})_{6} 5 \mathrm{mM} ; \mathrm{Na}_{2} \mathrm{SO}_{3} 30 \mathrm{mM}$; enzyme $100 \mu \mathrm{l}$

Activity measured in the direction of APS formation and monitored by decrease at $420 \mathrm{~nm}$ due to ferri-cyanide reduction

Assay vol: $2.0 \mathrm{ml} ; 2,2^{\prime}$-azinobis-3-ethyl

benz-thiazoline-6-sulphonic acid [ABTS], $0.5 \mathrm{mM} ; \mathrm{CH}_{3} \mathrm{COONa}$ pH 4, $50 \mathrm{mM}$; diphenol $0.5 \mathrm{mM}$; enzyme $100 \mu \mathrm{l}$

$1 \mathrm{U}$ enzyme $=1 \mu \mathrm{mol}$ product per minute

Monitoring oxidation of ABTS at $420 \mathrm{~nm}$

Assay vol: $3 \mathrm{ml}$; malonate buffer, $\mathrm{pH} 4.5 .50 \mathrm{mM}$;

2,6-dimethoxyphenol, $0.1 \mathrm{mM}, \mathrm{H}_{2} \mathrm{O}_{2}, 0.2 \mathrm{mM} ; \mathrm{MnSO}_{4} 1.0 \mathrm{mM}$; enzyme $100 \mu \mathrm{l}$

Activity monitored by oxidation of 2,6-dimethoxy-phenol at $470 \mathrm{~nm}$

Assay vol: $3.15 \mathrm{ml}$; methyl viologen, $1 \mathrm{mM}$ in Tris- $\mathrm{HCl}, 20 \mathrm{mM}$, pH 7.8; sodium dithionite, $100 \mathrm{mM}$; enzyme $100 \mu \mathrm{l}$

$1 \mathrm{U}$ enzyme $=$ reduction of $1 \mu \mathrm{mol}$ of methyl viologen per minute under $\mathrm{H}_{2}$ at $604 \mathrm{~nm}$

Assay vol: $1.0 \mathrm{ml}$; Tris- $\mathrm{HCl}$ buffer, $\mathrm{pH}$ 8.0, $50 \mathrm{mM}$; catechol $1 \mathrm{mM}$; enzyme $100 \mu l$

\section{Activity monitored at $260 \mathrm{~nm}$}

$1 \mathrm{U}$ enzyme $=\mu$ mole of catechol converted per minute

Assay vol: $1.0 \mathrm{ml}$; Tris- $\mathrm{HCl}$ buffer, $\mathrm{pH}$ 8.0, $50 \mathrm{mM}$; catechol $1 \mathrm{mM}$; enzyme $100 \mu 1$

Activity monitored at $375 \mathrm{~nm}$

$1 \mathrm{U}$ enzyme $=\mu$ mole of catechol converted per minute 


\begin{tabular}{ll}
\hline No. $[$ Ref $]$ & Classification; Properties \\
\hline $\begin{array}{l}1.13 .11 .18 . \\
{[154-156]}\end{array}$ & Sulphur dioxygenase
\end{tabular}

[154-156]

Sulphur dioxygenase

Reaction

Thiosulphate
oxidase
$\mathrm{SO}_{4} \longleftarrow$ $\mathrm{SO}_{4} \longleftarrow \mathrm{S}_{2} \mathrm{O}_{3} \longleftarrow$ Thiosulphate mechanism $\mathrm{Fe}^{+++} \mathrm{Fe}^{++}$ Polysulphide mechanism $\checkmark$

1.14.12 [82] Dioxygenases

Incorporation of both atoms of $\mathrm{O}_{2}$ into the product.

1.14 [83-85]

Monooxygenases

Incorporation of one atom of $\mathrm{O}_{2}$ into the product and the other reduced to $\mathrm{H}_{2} \mathrm{O}$

1.16.1.1 Reductase

$\begin{array}{ll}\begin{array}{c}\text { Mercuric } \\ \text { reductase }\end{array} & \text { Donors: Metal ions } \\ {[124,125]} & \text { Acceptors: } \mathrm{NAD}(\mathrm{P}) \mathrm{H}\end{array}$

Cupric

reductase

[119-121]

1.97 .1 [127-129]

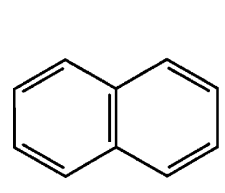

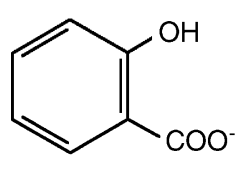

Salicylate

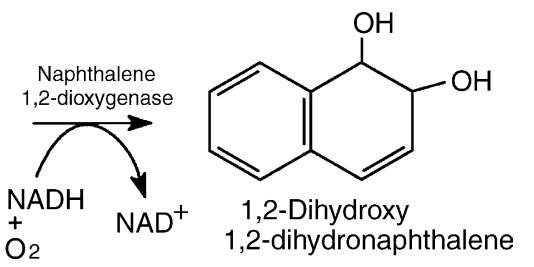

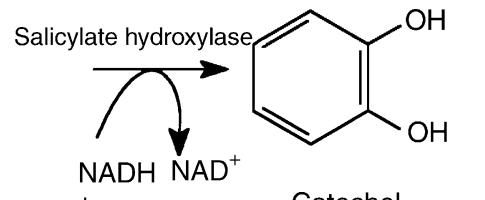

$\mathrm{O}_{2}$
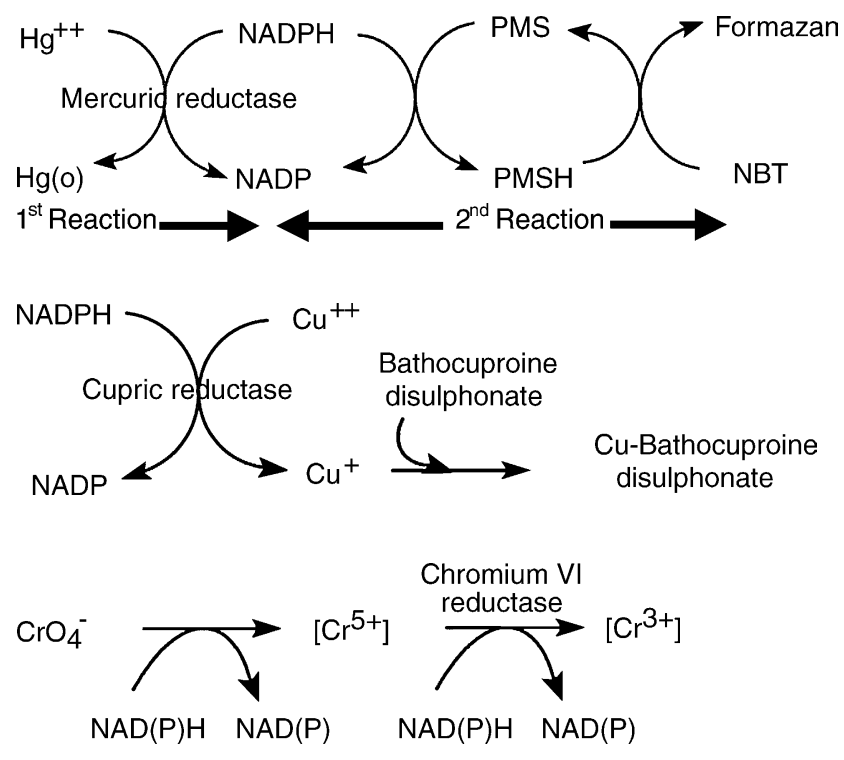

Assay vol: $1.0 \mathrm{ml}$; Tris-HCl, $\mathrm{pH} 7.5,50 \mathrm{mM}$, salicylate, $0.1 \mathrm{mM}$, $\mathrm{NADH}, 0.3 \mathrm{mM}$, ferrous ammonium sulphate, $0.1 \mathrm{mM}$, enzyme $100 \mu \mathrm{l}$

Assayed by decrease in $A_{340}$ due to decrease of NADH

Reagents; Assay

Assay vol: $1.0 \mathrm{ml}$; Tris-acetate buffer, $\mathrm{pH} 7.4,70 \mathrm{mM}$; sulphur 2\%; enzyme $200 \mu$ l; sulphite + thio-sulphate or sulphide were

determined colorimetrically

Assay vol: $1.0 \mathrm{ml}$; Tris- $\mathrm{HCl}, \mathrm{pH} 7.5,50 \mathrm{mM}$, indole, $0.1 \mathrm{mM}$, $\mathrm{NADH}, 0.3 \mathrm{mM}$, ferrous ammonium sulphate, $0.1 \mathrm{mM}$, enzyme $100 \mu l$

Assayed by decrease in $A_{340}$ due to decrease of NADH

Assay vol. $1.2 \mathrm{ml}$; enzyme $100 \mu \mathrm{l}$; phosphate buffer, $\mathrm{pH} 7.5$, $50 \mathrm{mM}$; NADPH, $100 \mu \mathrm{M}$; $\mathrm{Mg}(\mathrm{OAc})_{2}, 200 \mu \mathrm{M}$; EDTA, $500 \mu \mathrm{M}$; mercaptoethanol, $0.1 \% ; \mathrm{HgCl}_{2}, 200 \mu \mathrm{M} ; 60$ min in dark; phosphate buffer, $50 \mathrm{mM}, \mathrm{pH} 8.0$ with $10 \mathrm{mg}$ nitroblue tetrazolium (NBT) and $1.5 \mathrm{mg}$ phenazine methosulphate (PMS)

Enzyme activity determined at $590 \mathrm{~nm}$ from formazan standard curve

Assay vol: $400 \mu \mathrm{l}$; sodium citrate $\mathrm{pH} 7.5,200 \mathrm{mM} ; \mathrm{CuCl}_{2} 20 \mu \mathrm{M}$; bathocuproine disulphonate $100 \mu \mathrm{M}$; FAD $40 \mu \mathrm{M}$; NADH $100 \mu \mathrm{M}$; enzyme $100 \mu 1$

Assayed by increase in $A_{480}$ due to $\mathrm{Cu}^{+}$-batho-cuproine

Assay volume, $1.0 \mathrm{ml} ; \mathrm{H}_{2} \mathrm{SO}_{4}, 0.1 \mathrm{M} ; 1,5$-diphenyl-carbazide, $0.01 \%$, Tris-HCl buffer, $50 \mathrm{mM}, \mathrm{pH} 7, \mathrm{~K}_{2} \mathrm{CrO}_{4}, 0.05 \mathrm{mM}$. NADH, $0.1 \mathrm{mM}$; enzyme $100 \mu \mathrm{l}$

Assayed by decrease in $A_{540}$ due to decrease in chromate 


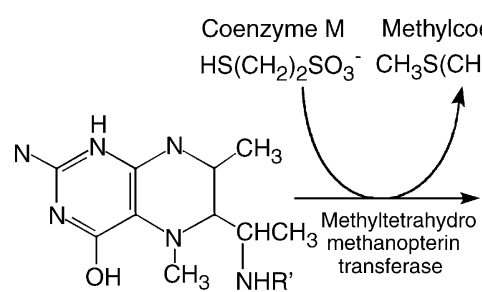

$\mathrm{OH} \quad \mathrm{CH}_{3} \quad \mathrm{NHR}^{2}$ Methyltetrahydro

\section{enzyme $\mathrm{M}$}

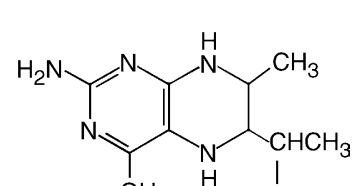

$\mathrm{OH} \mathrm{H} \stackrel{\mathrm{NHR}}{ }$ Tetrahydro
2.1.3.1

Transfer $\mathrm{C}_{1}$ carboxy group

Transketolase or transaldolase
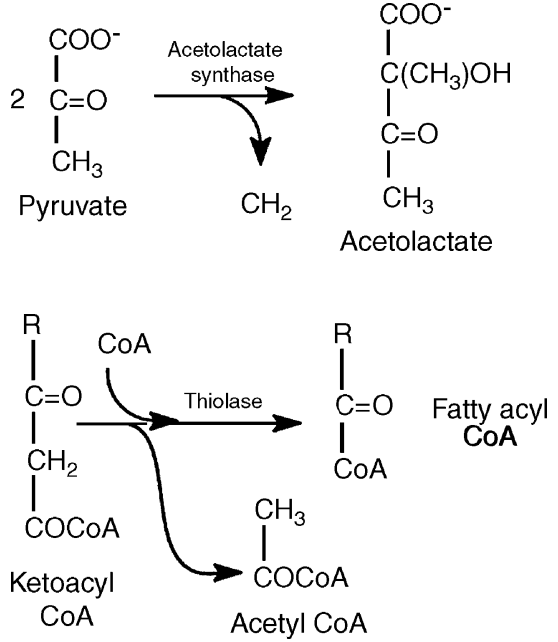

Assay vol: $100 \mu \mathrm{l}$; coenzyme M $6 \mathrm{mM}$; ATP $0.5 \mathrm{mM} ; \mathrm{CH}_{3}-\mathrm{H}_{4} \mathrm{MPT}$ $3 \mathrm{mM} ; \mathrm{MgSO}_{4} 1 \mathrm{mM}$; Ti(III)citrate $0.7 \mathrm{mM}$; DTT $1 \mathrm{mM}$; Phosphate buffer $\mathrm{pH}$ 7, $40 \mathrm{mM}$

Analysed by release of thiol with dithiobisnitro-benzene

$1 \mathrm{U}$ enzyme $=\mu$ mole of coenzyme $\mathrm{M}$ methylated per minute by $\mathrm{CH}_{3}-\mathrm{H}_{4} \mathrm{MPT}$

Assay vol: $600 \mu \mathrm{l}$; Tris-HCl buffer, $\mathrm{pH}$ 7.0, $15 \mu \mathrm{M}$; glutathione $3 \mu \mathrm{M}$; NADH $0.15 \mu \mathrm{M}$; pyruvate $6 \mu \mathrm{M}$; methylmalonyl CoA $0.5 \mu \mathrm{M}$; malic dehydrogenase $0.2 \mathrm{U}$

Assay monitored by change in $A_{340}$ by coupling with the reduction of oxaloacetate to malate and NAD

Assay vol: $1.0 \mathrm{ml}$; phosphate buffer, $\mathrm{pH} 7.8,50 \mathrm{mM}$; pyruvate $100 \mathrm{mM}$; thiamine diphosphate $1 \mathrm{mM} ; \mathrm{MgCl}_{2} 10 \mathrm{mM}$; FAD $10 \mu \mathrm{M}$

Activity monitored at $333 \mathrm{~nm}$ due to disappearance of pyruvate

$1 \mathrm{U}$ activity $=1 \mu \mathrm{mol}$ acetolactate formed per minute

Assay vol: $1.0 \mathrm{ml}$; Tris-HCl, pH 8.8, $50 \mathrm{mM}$; NADH $0.1 \mathrm{mM}$; 3-hydroxyacyl-CoA dehydrogenase $0.5 \mathrm{U} ; \mathrm{CH}_{3} \mathrm{COCoA} 1.5 \mathrm{mM}$; Formation of CoA measured with 5,5'-dithiobis(2-nitrobenzoic acid) at $412 \mathrm{~nm}$

Activity measured in the direction of ketoacylCoA formation by coupling with its reduction to 3-hydroxyacyl CoA and NAD 


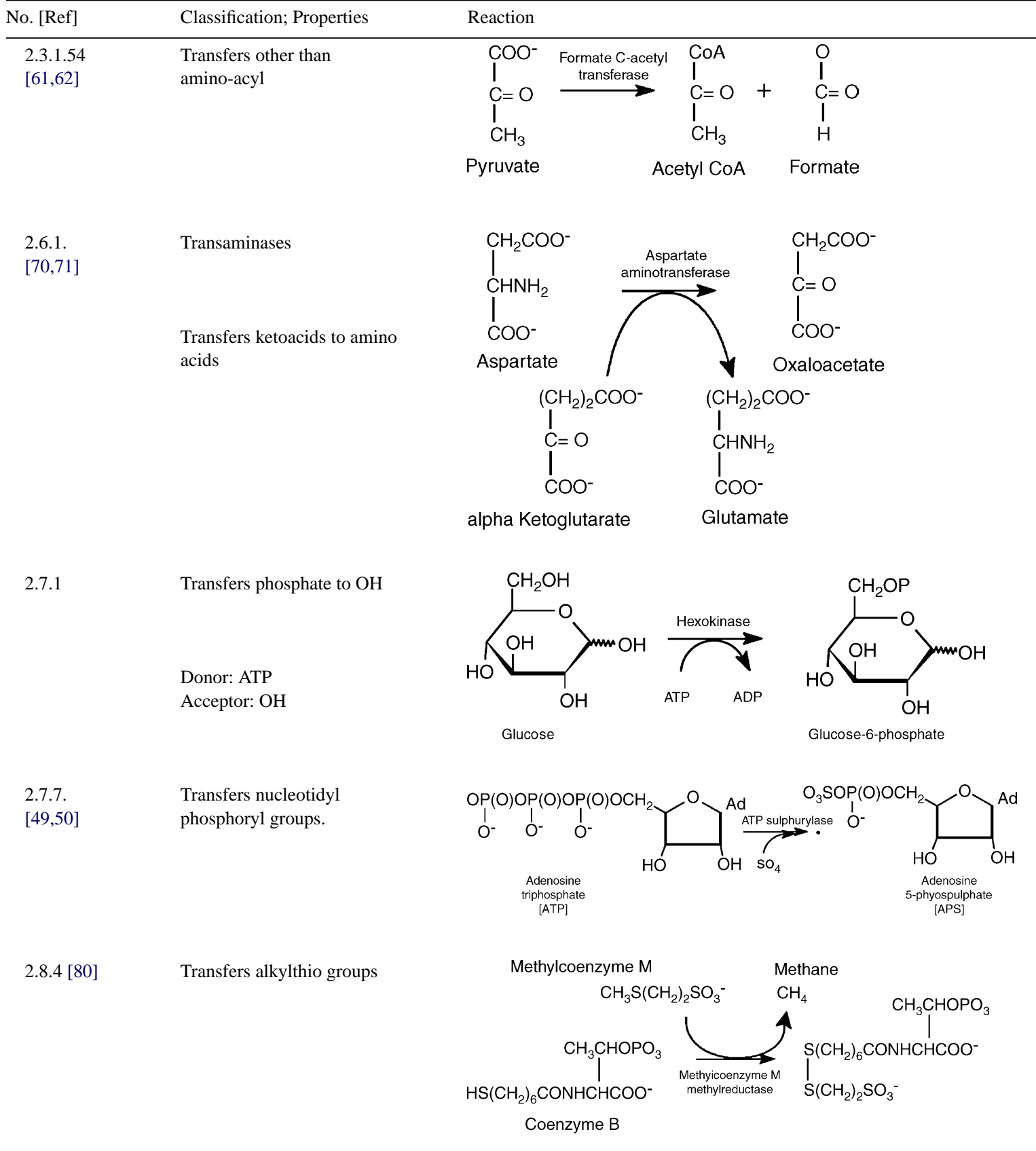

Reagents; Assay

Assay vol: $1.0 \mathrm{ml}$; phosphate buffer, pH 7.6, $100 \mathrm{mM}$; pyruvate

$20 \mathrm{mM}$; CoA $80 \mu \mathrm{M}$; NAD $1 \mathrm{mM}$; malate $6 \mathrm{mM}$; DTT $2 \mathrm{mM}$;

citrate synthase $1 \mathrm{U}$; malate dehydrogenase $22 \mathrm{U}$; enzyme $100 \mu \mathrm{l}$

Assay monitored by change in $A_{340}$

Assay vol: $3.0 \mathrm{ml}$; phosphate buffer, $\mathrm{pH} 7.5,100 \mathrm{mM}$; aspartate

$120 \mathrm{mM}$; NADH $3 \mathrm{mM}$; malate dehydrogenase $200 \mathrm{U}$;

$\alpha$-ketoglutarate $100 \mathrm{mM}$; enzyme $100 \mu \mathrm{l}$

Assay monitored by change in $A_{340}$ by coupling with the reduction of oxaloacetate to malate and NAD

Assay vol: $1.0 \mathrm{ml}$; Tris-HCl, pH 8.0, $100 \mathrm{mM}$; glucose $20 \mathrm{mM}$; ATP $1 \mathrm{mM}$; $\mathrm{NADP}^{+} 0.3 \mathrm{mM}$; glucose-phosphate dehydrogenase $2 \mathrm{U}$; enzyme $100 \mu \mathrm{l}$

Activity monitored at $340 \mathrm{~nm}$ by coupling with oxidation of glucose-6-phosphate to 6-phospho-gluconate and NADPH

Assay vol: $1.0 \mathrm{ml}$; Tris-HCl, pH 8.0, $100 \mathrm{mM}$; APS $1 \mathrm{mM}$; $\mathrm{MgCl}_{2}$ $1 \mathrm{mM}$; PPi $1 \mathrm{mM}$; enzyme $20 \mu \mathrm{l}$; reaction terminated with $\mathrm{NaOH}$, $6 \mathrm{M}, 100 \mu \mathrm{l}$. Centrifuged and aliquot used to measure ATP formation with standard hexokinase glucose-6-phosphate dehydrogenase coupled system

Activity measured in the direction of ATP formation

Assay vol: $8.0 \mathrm{ml}$; MOPS NaOH buffer, $\mathrm{pH} 7.2,500 \mathrm{mM}$; methyl coenzyme M $10 \mathrm{mM}$; coenzyme B $1 \mathrm{mM}$; aquacobalamin $0.3 \mathrm{mM}$ titanium citrate $30 \mathrm{mM}$; enzyme $100 \mu \mathrm{l}$; atmosphere $92 \% \mathrm{~N}_{2} / 8 \%$

$\mathrm{H}_{2}$. $\mathrm{CH}_{4}$ conc. determined by gas chromatography

$1 \mathrm{U}$ activity $=$ produces $1 \mu \mathrm{mol}$ methane per minute 
Enzymatic cleavage of glycerol from triacetin and reaction monitored at $570 \mathrm{~nm}$. Glycerol then determined by standard curve

Enzymatic cleavage of $\rho$-nitrophenolphosphate $(\rho$-NPP) to

$\rho$-nitrophenol $(\rho-\mathrm{NP})$ to generate ion, measured at $405 \mathrm{~nm}$, in alkaline solution

Sulphatases

Enzymatic cleavage of $\rho$-nitrophenolsulphate $(\rho$-NPS) to

$\rho$-nitrophenol $(\rho$-NP) to generate ion, measured at $405 \mathrm{~nm}$, in alkaline

solution

Methylumbelliferylglucopyranoside [MUG] is hydrolysed to methyl umbelliferone [MUF]

Proteases

Adds or removes $\mathrm{H}_{2} \mathrm{O}$
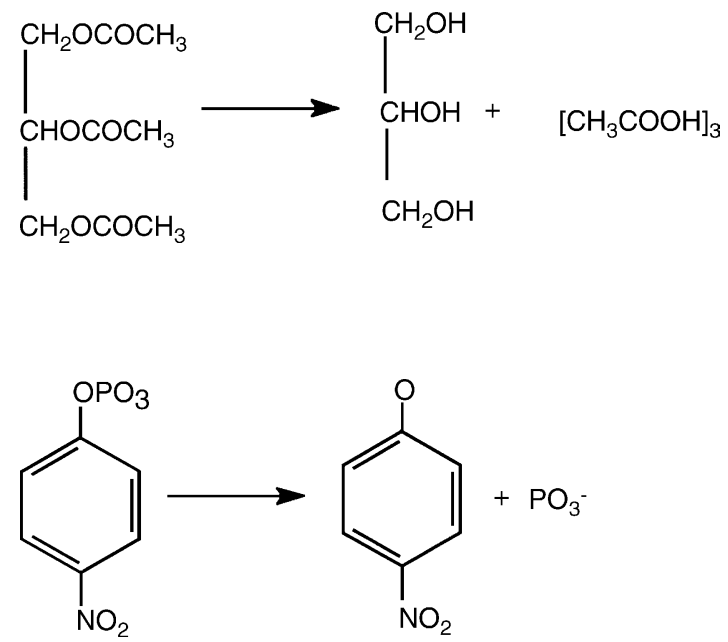<smiles></smiles>

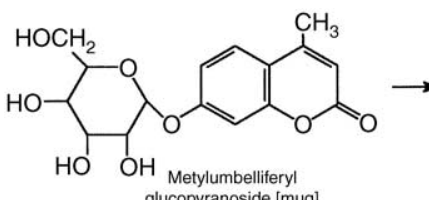<smiles>OCC1OC(O)C(O)C(O)C1O</smiles>
$\lambda_{\mathrm{OH}}$
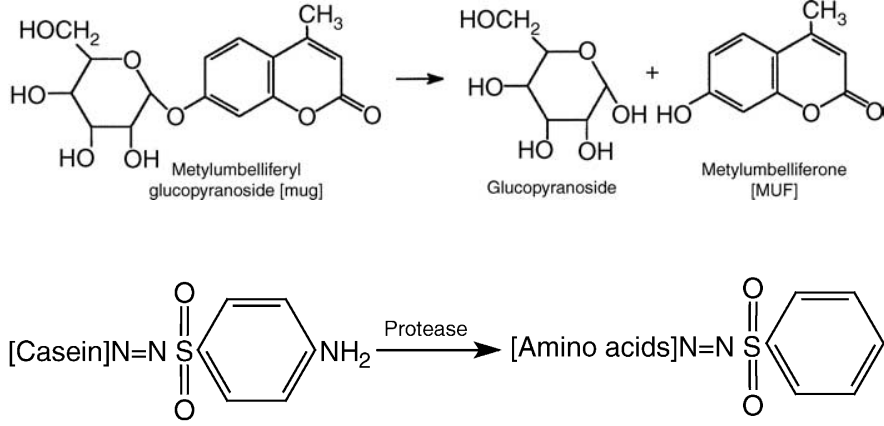

Assay vol: $5.0 \mathrm{ml}$; enzyme $1.0 \mathrm{ml} ; \rho$-NPP, $60 \mu \mathrm{M}$; acetate buffer, $10 \mathrm{mM}, \mathrm{pH} 8,25^{\circ} \mathrm{C}, 20 \mathrm{~min} ; \mathrm{NaOH}, 0.5 \mathrm{M}$ added

$1 \mathrm{U}$ of activity $=$ conversion $1 \mu \mathrm{mol} \rho$-NPP in $1 \mathrm{~min}$

Assay vol: $5.0 \mathrm{ml}$; enzyme $1.0 \mathrm{ml}$; $\rho$-NPS, $60 \mu \mathrm{M}$; acetate buffer, $10 \mathrm{mM}, \mathrm{pH} 8,25^{\circ} \mathrm{C}, 20 \mathrm{~min} ; \mathrm{NaOH}, 0.5 \mathrm{M}$ added

$1 \mathrm{U}$ of activity $=$ conversion $1 \mu \mathrm{mol} \rho$-NPS in $1 \mathrm{~min}$

vol: $5.0 \mathrm{ml}$; phosphate buffer, $0.1 \mathrm{M}, \mathrm{pH} 7.5$; triacetin. . w/v; enzyme $1.0 \mathrm{ml} ; \mathrm{H}_{2} \mathrm{SO}_{4}, 5 \mathrm{M}$; $\mathrm{NaIO}_{4}, 0.1 \mathrm{M}$; $\mathrm{NaHSO}_{3}$ mM; chromotropic acid, $2.5 \mathrm{~m}$

$1 \mathrm{U}$ activity $=$ forms $1 \mu \mathrm{mol}$ glycerol per minute

Fluorescence measured at $365 \mathrm{~nm}$ [excite] and $455 \mathrm{~nm}$ [emission] 


\begin{tabular}{cl} 
No. [Ref] & Classification; Properties \\
\hline $3.5 .4[78]$ & $\begin{array}{l}\text { Acting on carbon nitrogen } \\
\text { bonds of cyclic amidines }\end{array}$
\end{tabular}

Acting on carbon nitrogen
bonds of cyclic amidines

Reaction
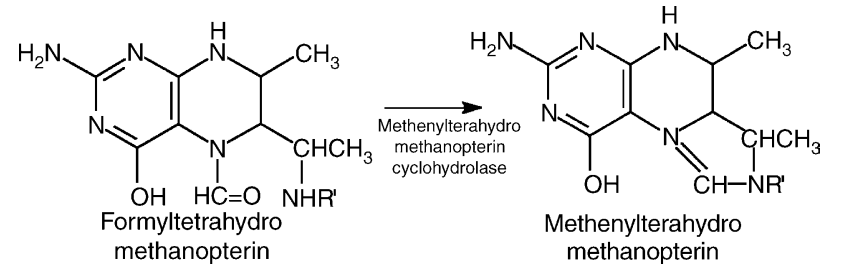

3.8 .1

Acting on C-halide bonds

Dehalogenase

Lyases

4

Carboxy lyase

Aldehyde lyase
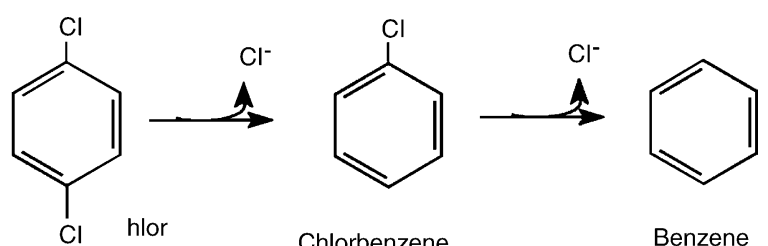

Benzene

Chlorbenzene Dichlorobenzene

Adds or removes a group other than $\mathrm{H}_{2} \mathrm{O}$.

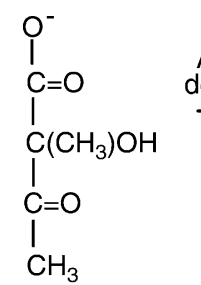

Acetolactate

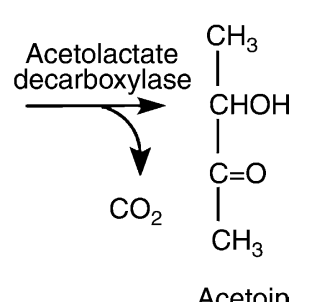

Acetoin

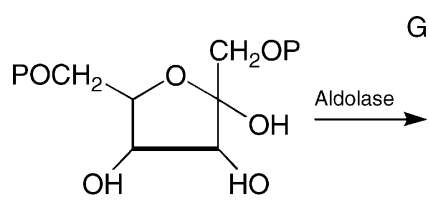

Fructose 1,6 diphosphate

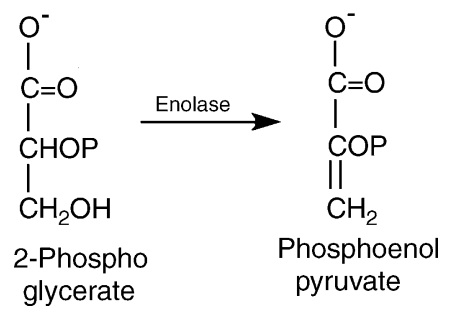

Reagents; Assay

Assay vol: $700 \mu \mathrm{l}$; Tricine- $\mathrm{KOH}, \mathrm{pH} 8.0,50 \mathrm{mM}$; $\mathrm{K}_{2} \mathrm{HPO}_{4} \mathrm{pH} 8.0$,

$1.5 \mathrm{M}$; methenyl- $\mathrm{H}_{4}-\mathrm{MPT}^{+}, 30 \mu \mathrm{M}$; enzyme $50 \mu \mathrm{l}$.

Activity measured in the direction of formyl $\mathrm{H}_{4}$ MPT and

monitored by decrease at $335 \mathrm{~nm}$ due to disappearance of methenyl $\mathrm{H}_{4}-\mathrm{MPT}^{+}$

$1 \mathrm{U}$ of activity $=1 \mu \mathrm{mol}$ methenyl $\mathrm{H}_{4}-\mathrm{MPT}^{+}$hydrolysed to formyl $\mathrm{H}_{4}$ MPT per minute

Assay vol: $1.0 \mathrm{ml}$; chlorobenzene, $0.3 \mathrm{pmol}$; phosphate buffer, $\mathrm{pH}$ $7.4,300 \mathrm{pmol}$; enzyme $200 \mu \mathrm{l}$; reduced glutathione, $13 \mathrm{pmol}, 0^{\circ} \mathrm{C}$, in phosphate buffer, $0.1 \mathrm{ml}$

Enzyme activity monitored as $\Delta A_{260}$ per unit time

Assay vol: $1.0 \mathrm{ml}$; phosphate buffer, pH 6.0, $50 \mathrm{mM}$; acetolactate $10 \mathrm{mM}$; enzyme $100 \mu \mathrm{l}$. After 5 min reaction quenched with $\mathrm{NaOH}$, $0.5 \mathrm{mM}$

Acetoin measured at $522 \mathrm{~nm}$ with naphthol, $1 \%+$ creatine $0.5 \%$ in $1 \mathrm{M} \mathrm{NaOH}$. Aliquot, $400 \mu \mathrm{l}+$ reagent $4.6 \mathrm{ml}$

$1 \mathrm{U}$ of activity $=1 \mu \mathrm{mol}$ acetoin produced per minute

Assay vol: $3.1 \mathrm{ml}$; fructose-1,6-biphosphate $12 \mathrm{mM}$; hydrazine sulphate $3.5 \mathrm{mM}$; EDTA, pH 7.5, $10 \mu \mathrm{M}$; enzyme $100 \mu \mathrm{l}$

Activity monitored at $240 \mathrm{~nm}$ due to formation of hydrazone with

3-phosphoglyceraldehyde

$\mathrm{CHO}$

$\stackrel{\mathrm{C}}{\mathrm{HOH}}+\underset{\mathrm{C}=\mathrm{O}}{\mathrm{C}}$

$\mathrm{CH}_{2} \mathrm{OP} \quad \mathrm{CH}_{2} \mathrm{OH}$

Assay vol: $1.0 \mathrm{ml}$; Tris-HCl, $\mathrm{pH}$ 8.0, $100 \mathrm{mM} ; \mathrm{MgSO}_{4} 2 \mathrm{mM}$; 2-phosphoglycerate $5 \mathrm{mM}$; enzyme $100 \mu \mathrm{l}$

Activity monitored from formation of phosphoenol-pyruvate at $240 \mathrm{~nm}$ 
Forming acid-thiol bonds

Formation of AMP is coupled enzymatically to myokinase (1) pyruvate kinase (2) and lactate dehydrogenase (3)

Interconverts aldoses and ketoses

Intramolecular transferases

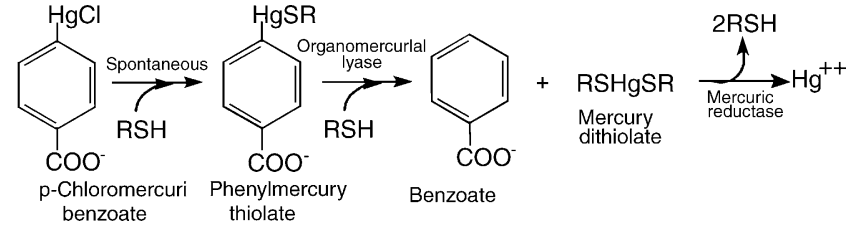

Catalyse geometric/structural changes within a molecule

Glyceraldehyde
3-phosphate

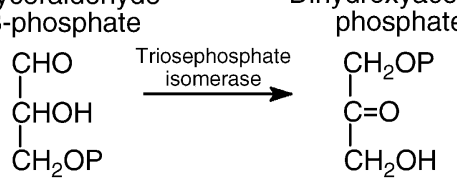

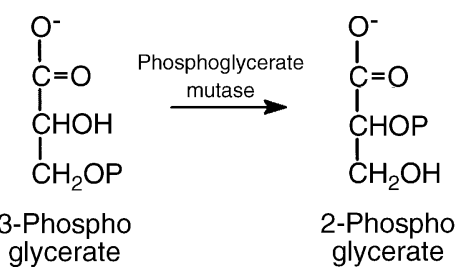

Joins groups together

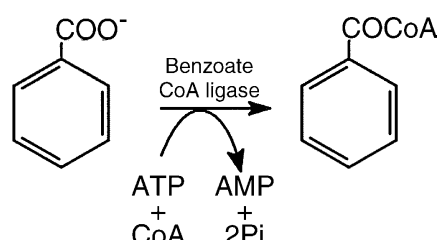

Assay vol: $1.0 \mathrm{ml}$; Tris- $\mathrm{HCl}, \mathrm{pH} 7.5,50 \mathrm{mM} ; \mathrm{p}-\mathrm{CMB}, 100 \mu \mathrm{M}$; L-cysteine, $1.0 \mathrm{mM}$; enzyme $100 \mu \mathrm{l}$

Enzyme activity is measured as $\Delta A_{250}$ with respect to time

Assay vol: $1.0 \mathrm{ml}$; HEPES buffer, pH 7.3, $100 \mathrm{mM}$; NADH $0.5 \mathrm{mM}$; glyceraldehydes-3-phosphate $4 \mathrm{mM}$; glycerol-phosphate dehydrogenase $4 \mathrm{U}$, enzyme $50 \mu$

Assay monitored by change in $A_{340}$

Assay vol: $1.0 \mathrm{ml}$; HEPES buffer, $\mathrm{pH} 7.4,25 \mathrm{mM}$; NADH $0.25 \mathrm{mM}$; 3-phosphoglycerate $5 \mathrm{mM} ; \mathrm{MgSO}_{4} 1 \mathrm{mM}$; ADP $1 \mathrm{mM}$; enolase $1 \mathrm{U}$; pyruvate kinase $1 \mathrm{U}$; lactate dehydrogenase $1 \mathrm{U}$; enzyme $100 \mu \mathrm{l}$

$1 \mathrm{U}$ activity $=$ converts $1 \mu \mathrm{mol} 3$-phosphoglycerate to 2-phosphoglycerate per minute

Assay monitored at $340 \mathrm{~nm}$

Assay vol: $1.0 \mathrm{ml} ; \mathrm{MgCl}_{2}, 2.5 \mathrm{mM}$; ATP $0.5 \mathrm{mM}$; CoASH, $0.25 \mathrm{mM}$ $\mathrm{KCl}, 10 \mathrm{mM}$; PEP, $10 \mathrm{mM}$; NADH, $0.35 \mathrm{mM} ; 2 \mathrm{U}$ of myokinase, pyruvate kinase, lactate dehydrogenase

Activity monitored by decrease $A_{340}$

$\mathrm{AMP}+\mathrm{ATP} \rightarrow 2 \mathrm{ADP}(\mathbf{1})$

$2 \mathrm{ADP}+2 \mathrm{PEP} \rightarrow 2$ pyruvate $+\mathrm{ATP}(\mathbf{2})$

2 pyruvate $+2 \mathrm{NADH} \rightarrow 2$ lactate $+\mathrm{NAD}(3)$ 


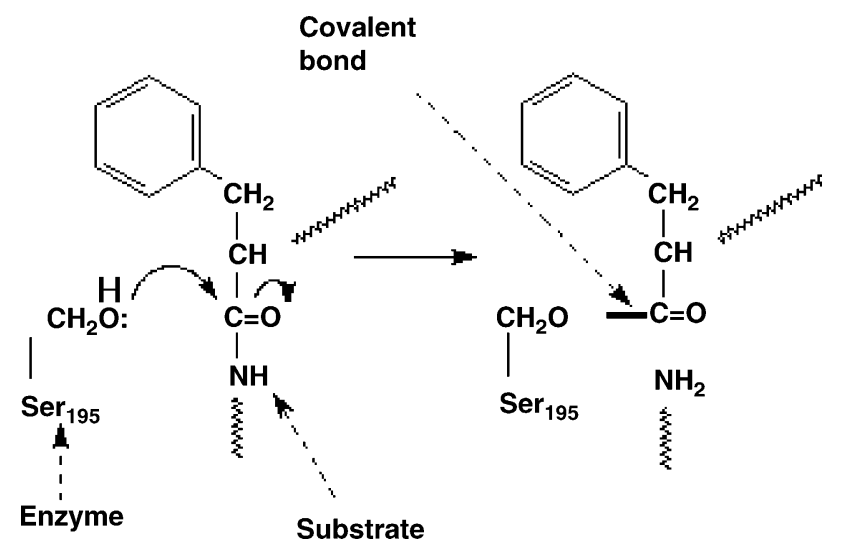

Fig. 7. Acyl covalent bond formation between an enzyme-serine and typical substrate.

the enzyme, which provides specific, high affinity binding of substrates and provides a favourable environment for catalysis.

After enzyme-substrate binding one, or more mechanisms of catalysis generates transition-state complexes and reaction products. (a) Destabilisation of ES complex may take place either by strain, distortion or desolvation. The zone of solvation around the substrate, while it is in solution, is lost as the substrate binds to the enzyme. The induced structural rearrangements that take place with the binding of substrate and enzyme ultimately produce strained substrate bonds, which more easily attain the transition state. (b) The substrate and enzyme when separate in solution are free to undergo translational motion leading to a disorientated high entropy situation while in the form of the ES complex they are both restricted and possess low entropy. (c) The substrate is orientated within the active site on the enzyme forming a covalent enzyme-substrate intermediate (Fig. 7) [30]. (d) General acid/base catalysis may occur where there is a transfer of a proton in the transition state either specifically by an acid or generally by some acidic/basic amino acid. (e) Some enzymes require metal ions to act as electrophilic catalysts that stabilise the increased electron density. (f) Enzyme substrate interactions induce strain in the substrate and orientate reactive groups into proximity with one another.

\subsection{Cofactors/coenzymes}

In many cases, a second component (cofactor, coenzyme or metal-ion activator) needs to be present on the active enzyme

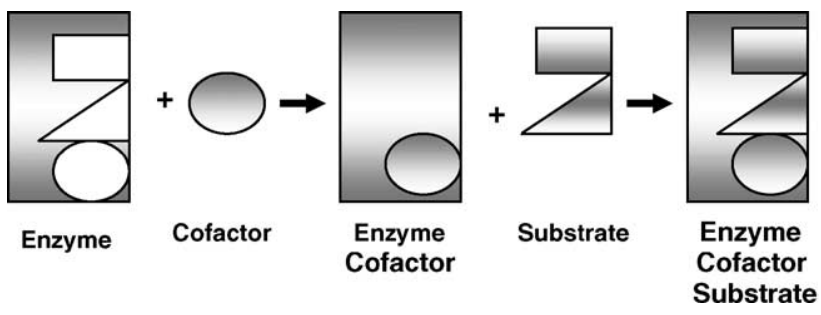

Fig. 8. Binding of substrate and cofactor to an enzyme.

before catalysis can occur. The apoenzyme is a term given to the protein portion of the inactive enzyme that initially binds to a prosthetic group, coenzyme or metal ion to produce the active holoenzyme. Even if the substrate is present at the active region of the enzyme catalysis does not occur until the second component is present (Fig. 8) [31].

\section{Enzymology of biological remediation}

\subsection{Aerobic digestion}

In the process of activated sludge floc-forming microbes degrade wastewater sludge, pollutants or any organic material, under aerobic conditions, to effect a biosolid-liquid separation. While a fraction of the organic material is used for the synthesis of new microorganisms, resulting in an increase in biomass, the remaining material is channeled into metabolic energy and oxidized to carbon dioxide, water, nitrates, sulphates and phosphates to provide energy for both synthesis and cellular functions (Fig. 9). The settled biosolids are subsequently recycled to aeration tanks in order to maintain the biomass concentration and the supernatant is discharged. Once the organic waste material becomes exhausted then the organisms will begin endogenous respiration to oxidize cellular material. Unfortunately, a disadvantage of an aerobic treatment is the production of large amounts of biosolids (sludge) which contains volatiles, organic solids, nutrients, pathogens, heavy metals, inorganic ions, toxic organic chemicals and the original problem of dissolved organic waste is now transformed into a problem of particulate waste. Aerobic respiration is defined as the aerobic catabolism of nutrients to carbon dioxide and water involving glycolysis, the tricarboxylic cycle, an electron transport system and molecular oxygen as the final electron acceptor: this type of aerobic digestion is notable in organisms that require molecular oxygen,

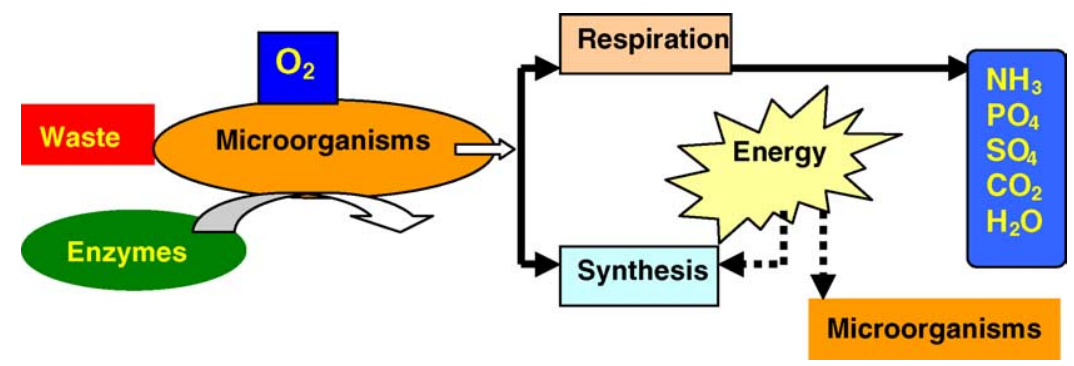

Fig. 9. Aerobic digestion of waste involving enzymes and microorganisms. 
and facultative anaerobes that are capable of aerobic respiration but can switch to fermentation if oxygen is unavailable. Typical assays for enzymes associated with this aerobic digestion (dehydrogenase EC. 1.1.1; kinase EC. 2.7.1; aldolase EC. 4.1.2; enolase EC. 4.2.1; isomerase EC. 5.3.1; mutase EC. 5.4.2, are listed; Table 2).

\subsection{Anaerobic digestion}

By definition anaerobic digestion is the breakdown of organic material into biogas $\left(\mathrm{CH}_{4}, \mathrm{CO}_{2}\right)$ and in which a molecule other than oxygen is the final electron acceptor. For example, sulphate-reducing bacteria transfer electrons to sulphate $\left(\mathrm{SO}_{4}{ }^{2-}\right)$ reducing it to $\mathrm{H}_{2} \mathrm{~S}$, while others (nitrate reducers) transfer the electrons to nitrate $\left(\mathrm{NO}_{3}{ }^{-}\right)$reducing it to nitrite $\left(\mathrm{NO}_{2}{ }^{-}\right)$, nitrous oxide (NO) or nitrogen gas $\left(\mathrm{N}_{2}\right)$. Alternative electron acceptors are $\mathrm{Fe}^{\mathrm{III}}$ and $\mathrm{Mn}^{\mathrm{IV}}$. It is critical that an understanding of the conditions, under which anaerobic digestion is taking place, be made before there can be any assessment of bioremediation potential. Amongst the many treatment technologies available, anaerobic treatment process has proved to be unique and the most beneficial stabilisation technique as it optimizes cost effectiveness, it is environmentally sound, minimises the amount of final sludge disposal and has an ability to produce a net energy gain in the form of methane gas [32]. The anaerobic treatment technology currently available, however, is only capable of partially treating waste in a conventional wastewater treatment system with high levels of degradation requiring longer retention times and/or further treatment methods [33].

It is commonly accepted that there are four distinct steps: (a) complex organic matter is decomposed into simple soluble organic molecules using water (hydrolysis) and hydrolase enzymes (glucosidases, lipases, proteases, sulphatases, phosphatases); (b) chemical decomposition of these single monomeric unit molecules (monosaccharides, amino acids, fatty acids, glycerol) into volatile fatty acids by a process termed acidogenesis; (c) acetogenic fermentation into acetate, $\mathrm{H}_{2}$ and $\mathrm{CO}_{2}$; (d) methanogenic conversion into $\mathrm{CH}_{4}$ and $\mathrm{CO}_{2}$ (Fig. 10).

\subsubsection{Hydrolysis}

Wastewater treatment bioreactors are complex ecosystems that contain a wide variety of organic substances and a mixed culture of heterogeneous microbial populations that effect sequential substrate removal when complex substrates are degraded. In such mixed cultures, sulphate-reducing bacteria (SRB) are able to compete, in the presence of sulphate, with methanogenic bacteria (MB) and acetogenic bacteria (AB) for the available substrates [34-36]. Biological anaerobic wastewater treatment systems, in which complex organic matter is completely degraded by SRB are a promising alternative for the methanogenic wastewater treatment systems [37] and the complex physico-chemical sulphate removal methods [38]. In conventional methanogenic anaerobic digestion systems, solubilisation rates for primary sewage sludge (PSS) are reported at about 10 days in yields of 5-10\% [39-43] while enhanced degradation of $52 \%$ has resulted under sulphidogenesis [44]. There is still no consensus, however, on the mechanism of enhanced hydrolysis though the key might be the activation of the hydrolytic enzymes through a sulphide gradient generated in situ during sulphate reduction [45].

Under anaerobic conditions the simple organic electron donor molecules, e.g. lactic acid, are used by the SRBs such as Desulfovibrio and Desulfuromonas to reduce sulphate to hydrogen sulphide and bicarbonate with a resultant increase in $\mathrm{pH}$ (Eq. (8)). Soluble metal salts react with $\mathrm{H}_{2} \mathrm{~S}$ in situ to produce insoluble metal sulphides, thereby reducing the concentration of metals and salts to acceptable levels (Eq. (9)). Bicarbonate ions react with protons to form $\mathrm{CO}_{2}$ and water, thus removing the 'acidity'

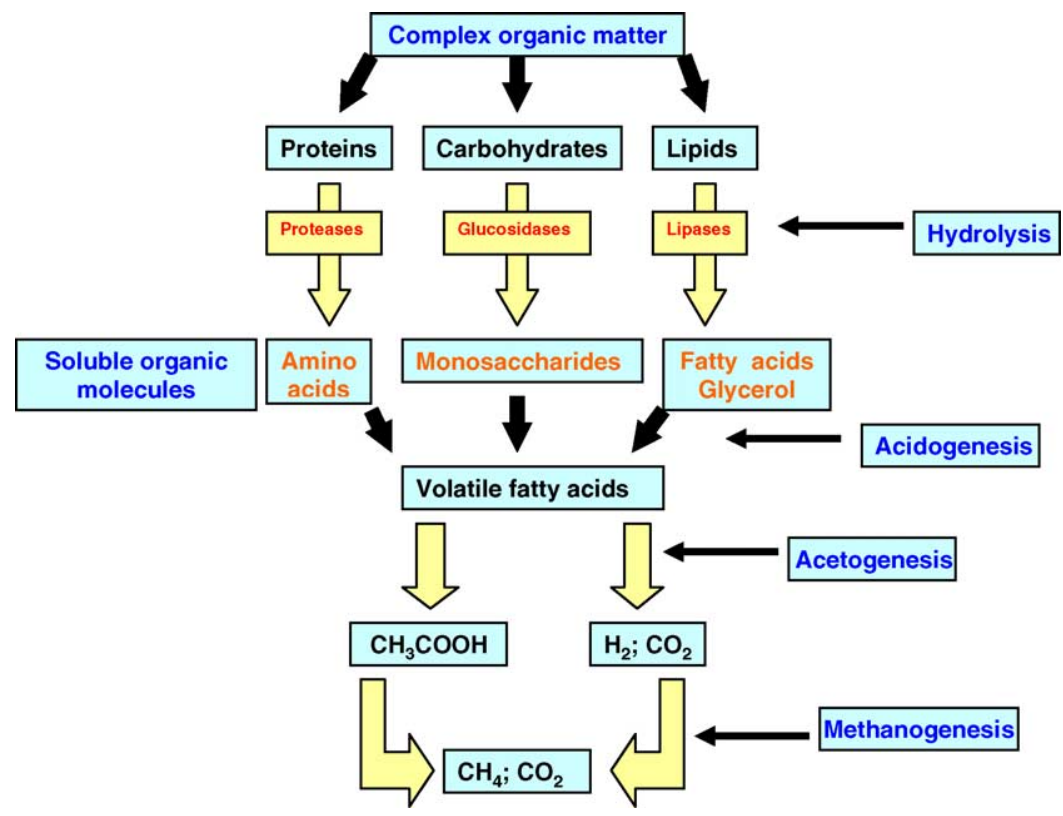

Fig. 10. Anaerobic digestion of complex organic matter into methane and carbon dioxide. 
from solution as $\mathrm{CO}_{2}$ gas (Eq. (10)).

$$
\begin{aligned}
& 3 \mathrm{SO}_{4}{ }^{2-}+\text { lactate } \rightarrow 3 \mathrm{H}_{2} \mathrm{~S}+6 \mathrm{HCO}_{3}{ }^{-} \\
& \mathrm{H}_{2} \mathrm{~S}+\mathrm{M}^{2+} \rightarrow \mathrm{MS}(\mathrm{s})+2 \mathrm{H}^{+} \\
& \mathrm{HCO}_{3}{ }^{-}+\mathrm{H}^{+} \rightarrow \mathrm{CO}_{2}(\mathrm{~g})+\mathrm{H}_{2} \mathrm{O}
\end{aligned}
$$

Sulphate-rich wastewater is produced by many industries such as sulphuric acid in food processes, thiosulphate in the photographic industry, sulphite in tanneries, the sea-food processing industry, the leaching of sulphur rich soils in land fills and mines and by power-plant flue gases from the combustion of sulphur containing fuel [46].

Several enzymes in anaerobic sulphate reduction are worthy of mention. Adenosine $5^{\prime}$-phosphosulphate (APS), synthesized from sulphate and ATP with the enzyme ATP sulphurylase (EC. 2.7.7, Table 2), serves as the nucleoside sulphate donor in this process, and therefore plays a crucial role in sulphate activation, the key step for sulphate utilisation [47-50]. APS is then broken down into sulphite and adenosine monophosphate (AMP) by APS reductase (EC. 1.8.99, Table 2) followed by a further reduction to sulphide by sulphite reductase (EC. 1.8.99, Table 2) [51].

In an extensive study on the enzymology within an anaerobic biosulphidogenic reactor [49,52-55], it was established that the enzymatic activities associated with sludge solubilisation and enhanced hydrolysis of complex polymeric organic carbon are found predominantly associated with the organic particulate network. Disruption of this network increases the susceptibility of the macromolecules, entrapped within the floc and hence protected from enzymatic degradation, to be attacked by the hydrolytic enzymes that would ultimately lead to enhanced solubilisation of sludge. The rate at which enzymatic hydrolysis proceeds is best described by first order kinetics as it is rate-limiting and is strongly influenced by environmental and operational parameters such as $\mathrm{pH}$, temperature, biomass, particle/floc size, type and concentration of particulate substrate and production concentration and by the reaction between the enzyme and its substrate [56]. Hydrolysis of these particulate organics is also enhanced in the presence of sulphide. The latter, apart from being a strong reducing agent and capable of reducing disulphide linkages that are essential for maintaining the three dimensional conformational structure, is also shown to increase the specific activity of all hydrolytic enzymes by nearly 5-10-fold [52-55]. Since the biopolymers (proteins, carbohydrates and lipids) are the major particulate organic fractions in sludge [57-59] the activities of the ubiquitous enzymes like lipases (EC. 3.1.1, Table 2), phosphatases (EC. 3.1.3, Table 2), sulphatases (EC. 3.1.6, Table 2), $\alpha$-, $\beta$-glucosidases and cellulases (EC. 3.2.1, Table 2), and proteases/peptidases (EC. 3.4, Table 2), are equally important in the hydrolysis process. It is proposed that the products of biological sulphate reduction both directly and indirectly facilitate the contact between enzyme and substrate thereby enhancing overall enzyme activity. This is due to the neutralisation of the ions on the floc surface by sulphide, sulphite and associated bicarbonate and hydroxide ions, destroying the overall integrity of the floc structure and exposing more substrate for enhanced enzyme activity [60]. Alternatively, the sulphite and sulphide species liberated during the sulphate reduction process, interact directly with the enzymes on the floc surface thereby enhancing their activity.

The initial development of anaerobic treatment processes, over a century ago, was for the treatment of domestic wastewaters, using anaerobic filters and hybrid processes that are still of interest today. Its applications then expanded to include separate sludge digestion and then to industrial wastewater. Biological stabilisation is widely considered to be one of the most attractive methods of reducing the major portion of the organic fraction in sludge, and anaerobic processes are favoured over aerobic digestion owing to the cost of aeration, the ability of anaerobic systems to maintain their temperature and the value of methane as a renewable energy source.

\subsubsection{Acidogenesis}

During this phase simple monosaccharides are converted via a series of acidogenic enzymes and the glycolytic pathway to ATP, NADH and pyruvate which is regarded as a key metabolite in anaerobic digestion. It is metabolized into acetyl CoA and formate through formate $\mathrm{C}$-acetyltransferase (pyruvate formate lyase) (EC. 2.3.1.54, Table 2) [61,62] or into lactate via reduction with lactate dehydrogenase (EC. 1.1.1, Table 2). In butanediol fermentation, two pyruvates are condensed with acetolactate synthase (EC. 2.2.1.6, Table 2) [63] to yield $\mathrm{CO}_{2}$ and acetolactate which is decarboxylated to acetoin (EC. 4.1.1.5, Table 2) [64] and eventually to 2,3-butanediol via a dehydrogenase [65]. Formate is converted by formate hydrogen lyase [66] to $\mathrm{H}_{2}$ plus $\mathrm{CO}_{2}$ while acetyl $\mathrm{CoA}$ is either reduced to acetaldehyde via acetaldehyde dehydrogenase and then to ethanol via alcohol dehydrogenase or converted to acetate via the high energy acetyl phosphate. Alternatively, two acetyl CoA molecules may condense producing acetoacetyl-CoA that can lose coenzyme $\mathrm{A}$ and $\mathrm{CO}_{2}$ to form acetone [67]. An initial transcarboxylase (EC. 2.1.3.1, Table 2) reaction with methylmalonyl SCoA results in a conversion of pyruvate into oxaloacetate with a concomitant release of propionyl CoA. The final step is the release of propionic acid when CoASH is transferred to succinate [68]. Succinate can also be converted to succinyl-SCoA, and then back to methylmalonyl-SCoA via methylmalonyl-SCoA mutase, a Vitamin $\mathrm{B}_{12}$ containing enzyme [69].

After an initial activation as their coenzyme A derivatives the long chain fatty acids are enzymatically degraded by sequential removal of two-carbon units liberating, after each cycle, acetyl CoA, which enters the metabolic pool and a fatty acid with two carbons less (EC. 2.3.1.16, Table 2). Propionyl CoA is the ultimate product in the case of a fatty acid with odd-numbered carbon atoms.

It is not the intention within the current article to give an indepth analysis of anaerobic amino acid degradation and readers are directed to two excellent reviews [70,71]. All twenty amino acids are first enzymatically deaminated, via respective transaminases (EC. 2.6.1, Table 2), before their carbon skeletons are subsequently degraded into seven different metabolites-pyruvate, acetyl CoA, acetoacetyl-CoA, $\alpha$-ketoglutarate, propionyl CoA, fumarate and oxaloacetate. 


\subsubsection{Acetogenesis}

Acetogenic enzymes convert the products of the acidogenic step into acetate, $\mathrm{H}_{2}$ and $\mathrm{CO}_{2}$ that ultimately are the substrates for the methanogenic breakdown.

\subsubsection{Methanogenesis}

This constitutes the enzymatic production of methane from acetate or from a reduction of $\mathrm{CO}_{2}$ (Eqs. (11) and (12)). Molecular hydrogen or reduced coenzyme $\mathrm{F}_{420}$ are the electron donors with mixed disulphides (coenzymes $\mathrm{M}$ and $\mathrm{B}$ ) as electron acceptors. Eight enzymes and a formyl, methenyl and methyl tetrahydromethanopterin are involved in the reduction of $\mathrm{CO}_{2}[72]$.

$$
\begin{aligned}
& \mathrm{CO}_{2}+4 \mathrm{H}_{2} \rightarrow \mathrm{CH}_{4}+2 \mathrm{H}_{2} \mathrm{O} \\
& \mathrm{CH}_{3} \mathrm{COO}-\rightarrow \mathrm{CH}_{4}+\mathrm{CO}_{2}
\end{aligned}
$$

Initially, methanofuran interacts with $\mathrm{CO}_{2}$ with assistance of formylmethanofuran dehydrogenase (EC. 1.2.99, Table 2) [73] to produce formylmethanofuran. Coupled with tetrahydromethanopterin and a series of enzymes involving a transferase, a cyclo-hydrolase (EC.3.5.4, Table 2) a dehydrogenase and a reductase (EC.1.5.99, Table 2) [74-78] the $\mathrm{C}_{1}$ unit is carried, via coenzyme $\mathrm{F}_{420}$ into methyltetrahydromethanopterin. In the final step, the $C_{1}$ unit is associated with coenzyme $\mathrm{M}$ and a transferase enzyme (EC. 2.1.1.86, Table 2) before being reduced to methane [79]. Coenzyme B (7-mercaptoheptanoylthreoninephosphate) reacts with methyl coenzyme M liberating methane and coenzyme-M-S-S-heptanoylthreonine phosphate under the influence of methyl reductase (EC. 2.8.4.1, Table 2) [80].

A slight variation is reported [81] for the anaerobic enzymatic conversion of acetate to methane (Eq. (12)). The acetate, that is first activated as its coenzyme A derivative, is oxidised to $\mathrm{CO}_{2}$ with carbon monoxide dehydrogenase while its methyl group is transferred via tetrahydrosarcinapterin to coenzyme $\mathrm{M}$. This methylcoenzyme $\mathrm{M}$ is reductively demethylated with coenzyme $\mathrm{B}$ to methane and the resulting heterodisulphides converted back to their sulphydryl forms.

\subsection{Bioremediation/biodegradation}

Polycyclic aromatic hydrocarbons (PAHs), widely distributed in the environment mainly from anthropogenic activities, are organic chemicals that are cytotoxic, mutagenic and carcinogenic. Aerobic degradation of PAHs is a benign process that involves the oxidation of the aromatic ring by specific dioxygenases and a complete biotransformation into carbon dioxide and water. Naphthalene, one of the simplest PAHs, serves as model for understanding their biodegradation. Naphthalene-1,2-dioxygenase (EC. 1.14.12, Table 2) catalyses the oxidation, with molecular oxygen, of naphthalene to cis-1,2-dihydroxy 1,2-dihydronaphthalene [82] while salicylate hydroxylase (monooxygenase) (EC.1.14.13, Table 2) oxidatively decarboxylates salicylate to catechol and carbon dioxide [83-85]. Both of these enzymes are assayed by measuring the decrease in absorbance at $340 \mathrm{~nm}$ due to the consumption of $\mathrm{NADH}$ in the presence of substrates.
All of the BTEX compounds (benzene, toluene, ethylbenzene and xylene) as well as the polychlorobenzenes (PCBs) have at least one aerobic pathway that includes degradation to a substituted catechol. Benzene is degraded to catechol; toluene has many separate biodegradative pathways, some of which include 3-methylcatechol as an intermediate product; ethylbenzene is degraded to 3-ethylcatechol; xylenes are all metabolized to mono-methylated catechols and the chlorobenzenes to chlorocatechol. In each of these cases, the aromatic ring of the substituted catechol is later cleaved by either an intradiol (orthocleaving) (EC.1.13.11.1, Table 2) catechol 1,2 dioxygenase or extradiol (metacleaving) catechol 2,3-dioxygenase enzyme (EC.1.13.11.2, Table 2). Subsequent metabolic pathways lead to acetaldehyde, acetate, succinate, pyruvate and eventually $\mathrm{CO}_{2}$ and $\mathrm{H}_{2} \mathrm{O}$.

It has recently been reported [86] that sulphate reducers are capable of degrading a wide variety of PAHs by modification of the aromatic ring - in particular demethylation, dehalogenation, reduction, removal of amino, hydroxyl and methoxyl groups as these processes detoxify potential xenobiotics [87-92]. In all of these enzymatic degradative pathways, the intermediate is an aromatic carboxylate coenzyme A thioester, formed through a benzoate CoA ligase (EC. 6.2.1.25, Table 2), leading to ring reduction, hydration, dehydrogenation, ring cleavage to 3-hydroxypimelyl CoA and eventually to acetyl CoA [93]. Naphthalene, toluene, ethylbenzene and xylene follow similar pathways initially involving a carboxylation of the aromatic ring while with the biodegradation of halobenzenes a series of dehalogenations with dehalogenases (EC. 3.8.1, Table 2) take place.

To date (2004), there are over 1000 enzymes reported to be involved in the biodegradation of aromatic systems, whether they be organic pollutants or not and it is beyond the scope of this paper to explore this any further. A description of all of these alternate pathways has appeared [94].

\subsection{Biopulping/biobleaching}

Biopulping is the treatment of lignocellulosic materials with oxidative lignin-degrading fungal enzymes prior to thermomechanical pulping. This biological process is reputed to increase paper-strength and reduce both chemical energy consumption and environmental impact. These enzymes, which include lignin and manganese peroxidase and laccase, are responsible for the oxidative biodegradation of PAHs (anthracene, benzo[a]pyrene) [95-101] into $\mathrm{CO}_{2}$ and $\mathrm{H}_{2} \mathrm{O}$. Lignin peroxidase (LiP) (EC.1.11.1, Table 2) use hydrogen peroxide to catalyze one-electron oxidations of phenolic and nonphenolic compounds leading to alkyl aryl cleavage, aromatic ring cleavage, demethylation, hydroxylation and polymerization while manganese peroxidase (MnP) (EC.1.11.1, Table 2) catalyze the Mn-mediated oxidation of lignin and phenolic compounds.

Laccases [p-diphenol-dioxygen oxidoreductase] (EC.1.10. 3.2 , Table 2) belong to the group of enzymes called blue copper oxidases that catalytically oxidise phenols [102] or chlorinated biphenyls with a four-electron reduction of $\mathrm{O}_{2}$ to $\mathrm{H}_{2} \mathrm{O}$. Artificial 
substrates such as ABTS (2,2' -azino-bis-3-ethylbenzthiazoline6-sulphonic acid), HBT (hydroxyl benzotriazole) or violuric acid can act as mediators enabling the oxidation of non-phenolic compounds which cannot be oxidized by laccases on their own, thereby expanding the range of applications of these enzymes [102].

It has been realized that thermostable xylanases can be implemented in biobleaching. [103] The process of lignin removal from chemical pulps to produce bright or completely white finished pulp is called 'bleaching.' Present-day bleaching of kraft pulp uses large amounts of chlorine-based chemicals and sodium hydrosulfite that produce toxic, mutagenic, persistent chemicals that bioaccumulate in biological systems. The main enzyme needed to enhance the delignification of kraft pulp is endo-xylanase, but enrichment with other enzymes such as mannanase, galactosidase, arabinosidase, glucosidase and xylosidase have been shown to improve the effect of enzymatic treatment of kraft pulp [104-107]. The enzyme does not bleach pulp, but rather changes the pulp structure thereby opening it up for further degradation. The cleavage of the carbohydrate portion of lignin-carbohydrate complex to produce smaller residual lignin molecules, which are easier to remove, is also a possible mechanism of xylanase prebleaching.

The decolourisation of textile dyes may also be regarded as a biobleaching process and the biological enzymatic treatment of industrial wastewater dyes remains one of the most challenging. Extensive studies are forthcoming on dye decolourisation by non-specific extracellular oxidative enzymes (lignin peroxidase, manganese peroxidase, copper-containing phenol oxidase) from white-rot fungi [108-113] though these all have limited potential in both efficiency and reliability. Aromatic azo-dyes, in particular, are environmentally toxic and mutagenic and their enzymatic degradation involves the anaerobic reduction of the azo bond $(-\mathrm{N}=\mathrm{N}-)$, with azo-reductases followed by an aerobic biotransformation of the generated aromatic amines into $\mathrm{CO}_{2}, \mathrm{NH}_{3}$ and $\mathrm{H}_{2} \mathrm{O}$. Mechanistically azo reductases (EC.1.7.1.6, Table 2) which may be classified as flavoenzymes [114], may either transfer reducing equivalents such as $\mathrm{NAD}(\mathrm{P}) \mathrm{H}$ to the azo dye directly or through redox mediators (RM) like methyl viologen, menadione, neutral red, janus green [115], anthroquinone-2-sulphonate (AQS) or anthroquinone-2,6-disulphonate (AQD) (EC.1.7.1.6, Table 2) [116].

\subsection{Bioleaching}

This is described as the extraction of metals from their respective ores by biotechnological processes and enzyme based technologies for metal removal present an economic alternative for today's mining, mineral and waste water treatment industries.

The role of enzymes in a bioleaching process may be associated with either: (i) active transport ATPases, e.g. cadmium, copper, arsenate or (ii) direct enzymatic removal, e.g. mercury, iron, chromate $[117,118]$. With respect to the former the best characterized system is that for the essential metal ion $\mathrm{Cu}$ (II) and its concentration in the cell is delicately balanced by means of CopA, CopB, CopC, CopD, CopY and CopZ ATPases [119].

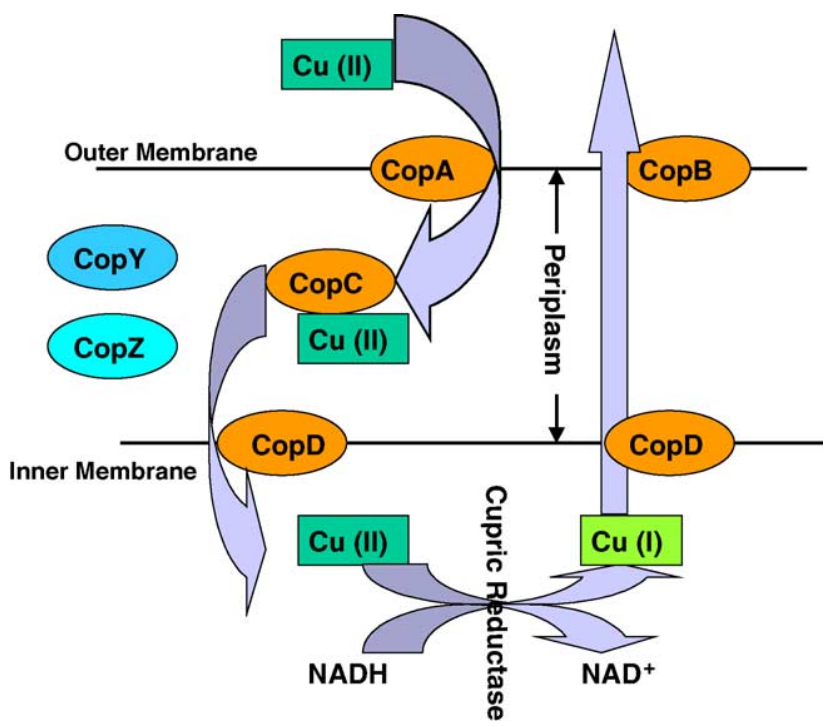

Fig. 11. Copper transport in Pseudomonas syringae [119].

Extracellular copper in the form of $\mathrm{Cu}$ (II) reaches the periplasmic space (Fig. 11) through the porous outer membrane assisted by CopA. A second ATPase, CopC, transports the copper to the inner membrane and to CopD that allows the copper to enter the cytoplasm. Here the $\mathrm{Cu}(\mathrm{II})$ is reduced to $\mathrm{Cu}(\mathrm{I})$ via a NADHcupric reductase system. Within the periplasm are two blue copper-binding proteins-CopY (repressor) and CopZ (chaperone) that sense levels of copper and switch off (or on) the respective operons. This allows for the export of $\mathrm{Cu}(\mathrm{I})$ through CopB [120,121]. The assay for cupric reductase is reported [122] (EC.1.16.1.1, Table 2).

Enzymatic processes, for the removal of metal ions from sludge waste effluent streams, use metal-desolubilising ligands on a continuous basis with extracellular or intracellular deposition of metals as a metal-ligand precipitate. Metal reduction usually results in the precipitation of low valence, reduced, forms of metals, and has therefore been proposed as a strategy to treat water contaminated with a range of metals and radionuclides. Mercury is a model example of an enzymatic removal process as it lends itself to inactivating essential thiols that are part of enzymes and proteins [123]. Some bacteria (Staphylococcus, Bacillus, Escherichia, Pseudomonas, Serratia, Thiobacillus) contain a set of genes that form a $\mathrm{Hg}(\mathrm{II})$ (mer) resistance operon which not only encodes for the production of a periplasmic metal binding enzyme that collects $\mathrm{Hg}$ (II) from the surrounding environment but also for a membrane associated transport enzyme that carries the $\mathrm{Hg}$ to the cytoplasm for removal. The first, organomercurial lyase (EC.4.99.1.2, Table 2) $[124,125]$ is effective in hydrolyzing the stable mercury-carbon bond by binding $\mathrm{Hg}$ (II) in the active site with cysteine sulphydryl residues. The mercury thiolate product is then utilized as a substrate for mercuric reductase (EC.1.16.1, Table 2) that contains the cofactor flavin in each of its subunits [121] and reduces $\mathrm{Hg}(\mathrm{II})$ to $\mathrm{Hg}(0)$ (metallic mercury), a process that involves hydride transfer from the electron carrier NADPH to flavin. Metallic mercury is then released to diffuse through the cell membrane and into the surrounding environment. 


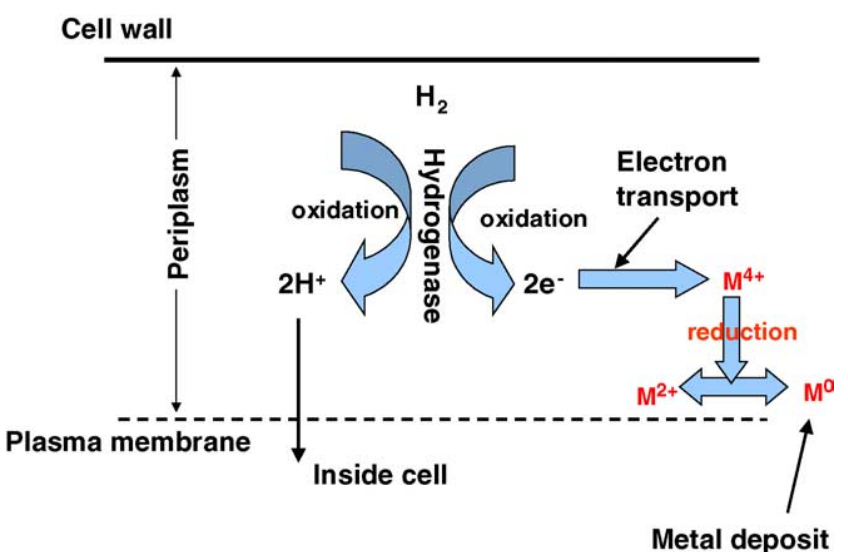

Fig. 12. Scheme of metal reduction by hydrogenase in sulphate reducing bacteria.

Chromium (VI) salts originate from industrial sources such as leather tanning, photographic-film making, wood preservation, car manufacturing, petroleum refining and agricultural activity [126]. Its reduction can occur under aerobic conditions using a soluble chromium reductase enzyme with either NADH or cytochrome $c_{3}$ to supply electrons [127,128] (EC.1.97.1, Table 2) or under anaerobic conditions with a hydrogenase or cytochrome $c_{3} / c_{7}$ type enzymes $[129,130]$ (Fig. 12). The majority of hydrogenases are metalloenzymes, and their metal sites belong to two main categories. First, the classical [2Fe-2S], $[3 \mathrm{Fe}-4 \mathrm{~S}]$ and $[4 \mathrm{FE}-4 \mathrm{~S}]$ iron sulphur clusters that shuttle electrons between the $\mathrm{H}_{2}$-activating site and the redox partners of hydrogenases [131] and second the $\mathrm{H}_{2}$-activating sites that appear as [NiFe], [Fe] [132] or metal free. The [4Fe-4S] cluster that is proximal to the active site is essential to $\mathrm{H}_{2}$ activation in [NiFe]-hydrogenases [133-137]. Protons generated from the oxidation of molecular hydrogen by hydrogenases are used for metabolic activities of the cell while the electrons released are channeled away to an electron acceptor through an electron transport chain [138] (Fig. 13). Ordinarily, this electron acceptor is the sulphate ion, but if these bacteria are presented with certain metal ions, they will use these as the electron sink,

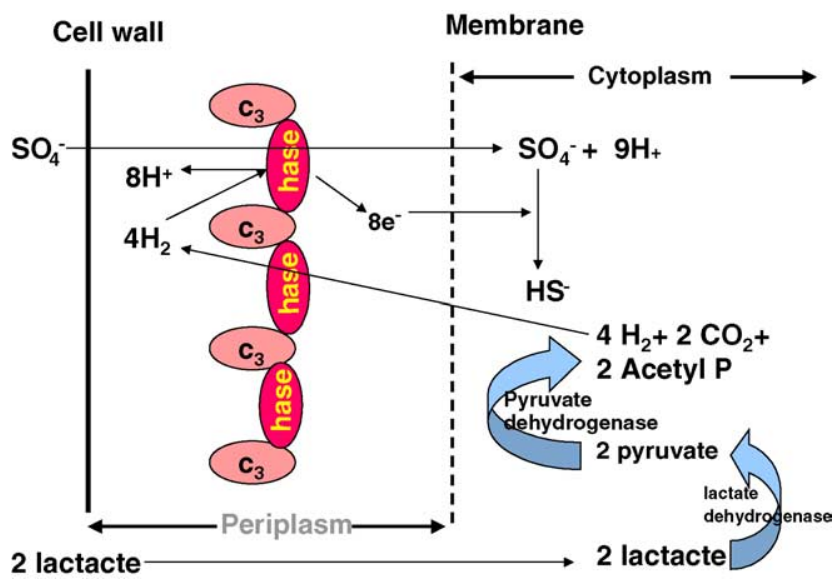

Fig. 13. Hydrogen cycling in Desulphovibrio vulgaris $\left(\mathrm{c}_{3}\right.$, cytochrome $c_{3}$; Hase, hydrogenase) [138]. leading to the reduction of the base metal, which is then precipitated from solution $[139,140]$. On the other side, lactate enters the cell and is oxidized to pyruvate by lactate dehydrogenases located on the internal aspects of the cytoplasmic membrane or cytoplasm [140]. Pyruvate is then converted to carbon dioxide, acetyl phosphate and electrons that are used to reduce protons to molecular hydrogen. The bioremediation of vanadium [141], uranium [142], cobalt and manganese [143], iron [144] and technetium [145-147] are reputed to follow similar enzymatic pathways.

Many explosives, such as trinitrotoluene (TNT) are enzymatically biodegraded either by an aerobic removal of the aromatic nitro groups [148] or by an anaerobic reduction to nitroso, hydroxylamino or amino groups $[149,150]$. In both cases, there is concomitant oxidation of $\mathrm{NAD}(\mathrm{P}) \mathrm{H}$ (EC.1.7.2.2; 1.7.99.3, Table 2). Explosives of this kind maybe the sole source of nitrogen in various anaerobic nitrate reducers that use nitrate $\left(\mathrm{NO}_{3}{ }^{-}\right)$, nitrite $\left(\mathrm{NO}_{2}{ }^{-}\right)$, nitric oxide $(\mathrm{NO})$ and nitrous oxide $\left(\mathrm{N}_{2} \mathrm{O}\right)$ as terminal electron acceptors. NADPH dependent nitrite reductase, which may either be a heme cytochrome cd1 (EC.1.7.2.2) or copper containing enzyme (EC.1.7.99.3) [151,152] has been isolated from Thiosphaera pantotropha and Paracoccus denitrificans while a [Fe] only hydrogenase has been found in Clostridium acetobutylicum [153].

The Gram-negative eubacterium Thiobacillus ferrooxidans is important for industry because it is able to solubilize copper, uranium, cobalt and iron metals from ores and contaminated industrial effluents by enzymatic oxidation. Two indirect oxidation mechanisms for this bioleaching exist. The one mechanism is exclusively based on the oxidative attack of iron(III) ions on the acid-insoluble metal sulfides, through a tentative thiosulphate oxidase and thiosulphate intermediate while the second mechanism allows for a dissolution by an attack of iron(III) ions and/or by protons with sulphur dioxygenase (EC.1.13.11.18, Table 2) and a polysulphide as an intermediate [154-156].

\section{Concluding comments}

The development and preparation of novel enzymes for use in biological remediation or for the industrial solubilisation of activated sludge remains a key challenge and a safe and economic alternative to commonly, and perhaps now redundant, physicochemical strategies. There are perhaps two approaches: rational and evolutionary. With the former, amino acid sequences, functional properties and structural features of different enzymes are compared, combined, then tested to see if the desired effect is accomplished. In the evolutionary design, a large library of random mutations in proteins is made followed by a selection of enzymes that work well with a particular contaminant. In principal, multiple environmental factors would 'select' enzymes to meet these challenges. Molecular evolution [157,158] is a useful tool for evolving enzymes with extended substrate specificities for any recalcitrant pollutant. Furthermore, this technology is more likely to 'succeed' then rational approaches as the latter requires multiple sets of structural and biochemical information on every enzyme involved. Sequences encoding specific enzymes can be retrieved direct from environmental samples 
thereby circumventing the process of isolating and screening wild-type organisms. Degenerate primers can be used to amplify central segments from these genes by PCR and inserted into the original functional gene. Such an approach allows rapid exploitation of the natural sequence diversity already present in the environment for creation of novel hybrid enzymes [159]. With the advent of molecular engineering the principle of developing a new "designer" enzyme and the creation of micro assemblers or microchips with the role of the computer as a delivery vehicle cannot be to far into the future.

One major feature to consider is to generate a new novel structure for use in activated floc solubilisation. In view of the extreme conditions that the activated sludge digesters may operate, the new enzyme molecules often have to be stable and active under unusual and extreme conditions of temperature, acidity, solvents, chemicals and pH. Enzyme properties, can be exploited to engineer active-site topology, to enlarge binding pockets and to alter the substrate specificity and stability. Consequently, the ability to modify a protein or structure to make it more stable to such conditions, or make it more resistant to self destruction, or make it target directed and functional in the presence of other toxic elements creates enormous challenges for enzymologists. Over the next 20 years, the enzyme-floc model will be exploited at a molecular level from a rational design to specific delivery of enzymes to the active areas disguised in vectors called nanoparticles. These will be the tools and scientific technological platforms for the investigation and transformations of any activated wastewater or biological system.

Under these pretexts biological remediations can only be rationalised by specific finite measurements, for each floc enzyme in the study, of maximal enzymatic rate $\left(V_{\max }\right)$, substrate specificity $\left(K_{\mathrm{m}}\right)$, turnover number $\left(k_{\text {cat }}\right)$, enzyme efficiency $\left(k_{\text {cat }} / K_{\mathrm{m}}\right)$.

\section{Acknowledgements}

The authors wish to thank the National Science Council, Taiwan and National Taiwan University, Taipei for financial support.

\section{References}

[1] Hankin L, Sands DC. Bacterial production of enzymes in activated sludge systems. J Water Pollut Control Fed 1974;46(8):2015-25.

[2] Teuber M, Brodish KEU. Enzymatic activities in activated sludge. Eur J Appl Microbiol 1977;4:185-94.

[3] Richards SR, Hastwell C, Davies M. The comparative examination of 14 activated sludge plants using enzymatic techniques. J Water Pollut Control Fed 1984;83(3):300-13.

[4] Lotter LH, van der Merwe EHM. The activities of some fermentation enzymes in activated sludge and their relationship to enhanced phosphorus removal. Water Res 1987;21(11):1307-10.

[5] Aitken MD. Waste treatment applications of enzymes: opportunities and obstacles. Chem Eng J 1993;52:B49-58.

[6] Allsopp D, Seal K, Gaylarde C. Introduction to biodeterioration. Cambridge University Press; 2004, ISBN 0521528879. p. 1-256.

[7] Volesky B, Holan ZR. Biosorption of heavy metals. Biotechnol Prog 1995;11(3):235-50.
[8] Gadd GM. Bioremedial potential of microbial mechanisms of metal mobilization and immobilization. Curr Opin Biotechnol 2000;11:2719.

[9] Gadd GM. Heavy metal pollutants: environmental and biotechnological aspects. In: Lederberg J, editor. The encyclopedia of microbiology. San Diego: Academic Press Inc; 2000. p. 607-17.

[10] Liu Y, Fang HHP. Influences of extracellular polymeric substances (EPS) on flocculation, settling and dewatering of activated sludge. Crit Environ Sci Technol 2003;33(3):237-73.

[11] Li D-H, Ganczarczyk JJ. Structure of activated sludge flocs. Biotechnol Bioeng 1990;35(1):57-65.

[12] Li D-H, Ganczarczyk JJ. Fractal geometry of particle aggregated in water and wastewater treatment processes. Environ Sci Technol 1989;23:1385-9.

[13] Jin B, Wilén B-M, Lant P. A comprehensive insight into floc characteristics and their impact on compressibility and settleability of activated sludge. Chem Eng J 2003;95(1-3):221-34.

[14] Ozinsky A, Ekama G. Secondary settling tank modeling and design. Part 2. Linking sludge settleability measures. Water SA 1995;21:333-49.

[15] Lee DJ, Chen GW, Liao YC, Hsieh CC. On the free-settling test for estimating ctivated sludge floc density. Water Res 1996;30:541-50.

[16] Lee D, Waite T, Wu R. Multilevel structure of sludge flocs. J Colloid Interface Sci 2002;252:383-92.

[17] Wilén B, Jin P, Lant P. Impacts of structural and microbial characteristics on activated sludge floc stability. Water Res 2003;37:3632-45.

[18] Mikkelsen LH, Keiding K. Physicochemical characteristics of full scale sewage sludges with implications to dewatering. Water Res 2002;36:2451-62.

[19] Barber J, Veenstra J. Evaluation of biological sludge properties influencing volume reduction. J Water Pollut Control Fed 1986;58(2):149-55.

[20] Wingender J, Neu TR, Fleming H-C. What are bacterial extracellular polymeric substances? In: Wingender J, Neu TR, Fleming H-C, editors. Microbial extracellular substances. Berlin, Germany: Springer; 1999. p. 1-19.

[21] Urbain V, Block JC, Manem J. Bioflocculation in activated sludge: an analytical approach. Water Res 1993;27(5):829-38.

[22] Frølund B, Palmgren R, Keiding K, Nielsen PH. Extraction of extracellular polymers from activated sludge using a cation exchange resin. Water Res 1996;30:1749-58.

[23] Jorand F, Boue-Bigne F, Block JC, Urbain V. Hydrophobic/hydrophilic properties of activated sludge exopolymeric substances. Water Sci Technol 1998;37(4/5):307-15.

[24] Liao B, Allen D, Droppo G, Leppard G, Liss S. Surface properties of sludge and their role in bioflocculation and settleability. Water Res 2001;19:527-33.

[25] Keiding K, Wybrandt L, Nielsen PH. Remember the water-a comment on EPS colligative properties. Water Sci Technol 2001;43(6):17-23.

[26] Stoscheck CM. Quantitation of protein. Methods Enzymol 1990;182: 50-69.

[27] Lineweaver H, Burk D. The determination of enzyme dissociation constants. J Amer Chem Soc 1934;56:658-66.

[28] Report of the Commission on Enzymes of the International Union of Biochemistry. Oxford: Pergamon Press; 1961.

[29] Enzyme Nomenclature. Nomenclature Committee of the International Union of Biochemistry and Molecular Biology. New York: Academic Press; 1992.

[30] http://search.netscape.com/ns/boomframe.jsp.

[31] http://tsailab.tamu.edu/biochem410_2004/13EnzymesIntroTransSActE.pdf.

[32] De Baere L. Anaerobic digestion of solid waste: state of the art. Water Sci Technol 2000;41:283-90.

[33] Parker NC, Fedler CB, Bush R. The 1998 ASAE Annual International Meeting, Paper No. 984102. 1998.

[34] Oude Elferink SJWH, Visser A, Hulshoff Pol LW, Stams AJM. Sulphate reduction in methanogenic bioreactors. FEMS Microbiol Rev 1994;15:119-36. 
[35] Colleran E, Finnegan S, Lens P. Anaerobic treatment of sulphatecontaining waste streams. Antonie van Leeuwenhoek 1995;67:2946.

[36] Omil F, Lens P, Visser A, Hulshoff Pol L, Lettinga G. Long term competition between sulphate reducing and methanogenic bacteria in UASB reactors treating volatile fatty acids. Biotechnol Bioeng 1998;57:676-85.

[37] Lens PNL, Visser A, Janssen AJH, Hulshoff-Pol LW, Lettinga G. Biotechnological treatment of sulphate-rich wastewaters. Crit Rev Environ Sci Technol 1998;28(1):41-88.

[38] Maree JP, Hulse G, Dods D, Schutte CE. Pilot plant studies on biological sulphate removal from industrial effluent. Water Sci Technol 1991;23(7-9):1230-300.

[39] Banister SS, Pretorius WA. Optimisation of sludge acidogenic fermentation for biological nutrient removal. Water SA 1998;24:3541.

[40] Canziani R, Pollice A, Ragazzi M. Design considerations on primary sludge hydrolysis under psychrophilic conditions. Environ Technol 1996;17:747-54.

[41] Elefsiniotis P, Oldham WK. Anaerobic acidogenesis of primary sludge: the role of solids retention time. Biotechnol Bioeng 1994;44:7-13.

[42] Hatziconstantinou GJ, Yannakopoulos P, Andreadakis A. Primary sludge hydrolysis for biological nutrient removal. Water Sci Technol 1996;34:417-23.

[43] Shimizu T, Kudo K, Nasu Y. Anaerobic waste activated sludge digestion: a bioconversion mechanism and kinetic model. Biotechnol Bioeng 1993;41:1082-91.

[44] Whittington-Jones K. Sulphide-enhanced hydrolysis of primary sewage sludge: implications for the bioremediation of sulphate-enriched wastewaters. PhD thesis. Grahamstown, South Africa: Rhodes University; 2000

[45] Whiteley CG, Pletschke BI, Rose PD, Tshivhunge AS, Watson SD, Whittington-Jones K. Activation of proteases in an anaerobic sulphidogenic bioreactor. Biotechnol Lett 2004;26(1):55-9.

[46] Weijma J, Stams AJM, Hulshoff Pol LW, Lettinga G. Thermophilic sulphate reduction and methanogenesis with methanol in a high rate anaerobic reactor. Biotechnol Bioeng 2000;67:354-63.

[47] Gavel OY, Bursakov SA, Calvete JJ, George GN, Moura JJG, Moura I. ATP sulphurylases from sulphate-reducing bacteria of the genus Desulphovibrio. A novel metalloprotein containing cobalt and zinc. Biochemistry 1998;37:16225-32.

[48] Dahl C, Speich N, Trüper HG. Enzymology and molecular biology of sulphate reduction in extremely thermophilic archaeon Archaeglobus fulgidus. Methods Enzymol 1994;243:331-49.

[49] Pletschke BI, Rose PD, Whiteley CG. Environmental enzymology: enzymology of accelerated sludge solubilisation: role of ATP sulphurylases. Enzyme Microbiol Technol 2002;31(3):329-36.

[50] Sperling D, Kappler U, Wynen A, Dahl C, Trüper HG. Dissimilatory ATP sulphurylase from the hyperthermophilic sulphate reducer Archaeglobus fulgidus belongs to the group of homo-oligomeric ATP sulphurylases. FEMS Microbiol Lett 1998;162:257-64.

[51] Dahl C, Truper HG. Sulfite reductase and APS reductase from Archaeoglobus fulgidus. Methods Enzymol 2001;331:427-41.

[52] Pletschke BI, Watson SD, Akhurst T, Whiteley CG, Rose PD. Primary sludge floc degradation is accelerated under biosulphidogenic conditions. Enzymological aspects. Enzyme Microbiol Technol 2004;34:595-602.

[53] Whiteley CG, Pletschke BI, Rose PD, Ngesi N. Specific sulphur metabolites stimulate $\beta$-glucosidase activity in an anaerobic sulphidogenic bioreactor. Biotechnol Lett 2002;24(18):150913.

[54] Whiteley CG, Pletschke BI, Rose PD, Enongene G, WhittingtonJones K. Co-digestion of primary sewage sludge and industrial wastewater under anaerobic sulphate reducing conditions: enzymatic profiles in a reciprocating sludge bed reactor. Water Sci Technol 2003;48(4):129-38.

[55] Whiteley CG, Heron P, Pletschke BI, Rose PD, Tshivhunge AS, van Jaarsveld FP, et al. The enzymology of sludge solubilisation utilising sulphate reducing systems. Properties of proteases and phosphatases. Enzyme Microbiol Technol 2002;31(4):419-25.

[56] Jain S, Lala AK, Bhatia SK, Kudchadker AP. Modelling of hydrolysis controlled anaerobic digestion. J Chem Tech Biotechnol 1992;53:337-44.

[57] Nielsen PH, Frølund B, Keiding K. Changes in the composition of extracellular polymeric substances in activated sludge during anaerobic storage. Appl Microbiol Biotechnol 1996;44(6):823-30.

[58] Houghton JI, Quarmby J. Biopolymers in wastewater treatment. Curr Opin Biotechnol 1999;10:259-62.

[59] Nielsen PH, Raunkjaer K, Norsker NH, Jensen NA, Hvitved-Jacobsen T. Transformation of wastewater in sewer systems. A review. Water Sci Technol 1992;27:17-31.

[60] Nielsen PH, Keiding K. Disintegration of activated sludge flocs in the presence of sulphide. Water Res 1998;32(2):313-20.

[61] Becker A, Fritz-Wolf K, Kabsch W, Knappe J, Schultz S, Volker Wagner AF. Structure and mechanism of the glycyl radical enzyme pyruvate formate-lyase. Nat Struct Biol 1999;6:969-75.

[62] Gelius-Dietrich G, Henze K. Pyruvate formate lyase (PFL) and PFL activating enzyme in the chytrid fungus Neocallimastix frontalis: a freeradical enzyme system conserved across divergent eukaryotic lineages. J Eukaryot Microbiol 2004;51(4):456-63.

[63] Aristidou AA, San KY. Bennett GN 1999 Metabolic flux analysis of Escherichia coli expressing the Bacillus subtilis acetolactate synthase in batch and continuous cultures. Biotechnol Bioeng 1999;63:73749.

[64] Curic M, Stuer-Lauidsen B, Renault P, Nilsson D. A general method for selection of an acetolactate decarboxylase deficient Lactococcus lactis mutants to improve diacetyl formation. Appl Environ Microbiol 1999;65(3):1202-6.

[65] Shimizu S, Kataoka M. Production of chiral C3- and C4-units by microbial enzymes. In: Advances in biochemical engineering/biotechnology. Springer-Verlag Heidelberg, 63; 2003. p. 109-23.

[66] Bagramyan K, Trchounian A. Structural and functional features of formate hydrogen lyase, an enzyme of mixed-acid fermentation from Escherichia coli. Biochemistry (Moscow) 2003;68(11):1159-70.

[67] Janssen PH, Schink B. Catabolic and anabolic enzyme activities and energetics of acetone metabolism of the sulfate-reducing bacterium Desulfococcus biacutus. J Bacteriol 1995;177(2):277-82.

[68] Zhang W, Reynolds KA. MeaA, a putative coenzyme B12-dependent mutase, provides methylmalonyl coenzyme A for monensin biosynthesis in Streptomyces cinnamonensis. J Bacteriol 2001;183(6):207180.

[69] Miyamoto E, Watanabe F, Charles TC, Yamaji R, Inui H, Nakano Y. Purification and characterization of homodimeric methylmalonylCoA mutase from Sinorhizobium meliloti. Arch Microbiol 2003;180(2): 151-4.

[70] Barker HA. Amino acid degradation by anaerobic bacteria. Ann Rev Biochem 1981;50:23-40.

[71] Heider J, Fuchs G. Microbial anaerobic aromatic metabolism. Anaerobe 1997;3:1-22.

[72] Deppenmeier U. The unique biochemistry of methanogenesis. Prog Nucleic Acid Res Mol Biol 2002;71:223-83.

[73] Bertram PA, Thauer RK. Thermodynamics of the formylmethanofuran dehydrogenase reaction in Methanobacterium thermoautotrophicum. Eur J Biochem 1994;226(3):811-8.

[74] Hartmann GC, Klein AR, Linder M, Thauer RK. Purification, properties and primary structure of $\mathrm{H}_{2}$-forming $\mathrm{N}_{5}, \mathrm{~N}_{10^{-}}$ methylenetetrahydromethanopterin dehydrogenase from Methanococcus thermolithotrophicus. Arch Microbiol 1996;165(3):187-93.

[75] Brommelstroet BW, Hensgens CM, Keltjens JT, van der Drift C, Vogels GD. Purification and characterization of coenzyme $\mathrm{F}_{420}$-dependent 5,10-methylene-tetrahydromethanopterin dehydrogenase from Methanobacterium thermoauto-trophicum strain delta $\mathrm{H}$. Biochim Biophys Acta 1991;1073(1):77-84.

[76] Ma K, Thauer RK. Purification and properties of $\mathrm{N}_{5}-, \mathrm{N}_{10}$-methylenetetrahydro-methanopterin reductase from Methanobacterium thermoautotrophicum (strain Marburg). Eur J Biochem 1990;191(1):187-93. 
[77] Donnelly MI, Wolfe RS. The role of formylmethanofuran: tetrahydromethanopterin formyltransferase in methanogenesis from carbon dioxide. J Biol Chem 1986;261(35):16653-9.

[78] Vaupel M, Dietz H, Linder D, Thauer RK. Primary structure of cyclohydrolase (Mch) from Methanobacterium thermoautotrophicum (strain Marburg) and functional expression of the mch gene in Escherichia coli. Eur J Biochem 1996;236(1):294-300.

[79] Harms U, Weiss DS, Gartner P, Linder D, Thauer RK. The energy conserving $\mathrm{N}_{5}$-methyl-tetrahydromethanopterin:coenzyme M methyltransferase complex from Methanobacterium thermoautotrophicum is composed of eight different subunits. Eur J Biochem 1995;228(3): 640-8.

[80] Ermler U, Grabarse W, Shima S, Goubeaud M, Thauer RK. Crystal structure of methyl-coenzyme $M$ reductase: the key enzyme of biological methane formation. Science 1997;278(5342):1457-62.

[81] Ferry JG. Enzymology of the fermentation of acetate to methane by Methanosarcina thermophila. Biofactors 1997;6(1):25-35.

[82] Eaton RW, Chapman PJ. Bacterial metabolism of naphthalene: construction and use of recombinant bacteria to study ring cleavage of 1,2-dihydroxynaphthalene and subsequent reactions. J Bacteriol 1992;174(23):7542-54.

[83] Bosch R, Moore ERB, Garcia-A-Valdes E, Pieper DH. NahW, a novel, inducible salicylate hydroxylase involved in mineralization of naphthalene by Pseudomonas stutzeri AN10. J Bacteriol 1999;181(8):2315-22.

[84] Suzuki K, Gomi T, Itagaki E. Intermediate and mechanism of hydroxylation of $o$-iodophenol by salicylate hydroxylase. J Biochem (Tokyo) 1991;109(5):791-7.

[85] You K, Bittikofer JA. Quantitation of salicylate in serum by use of salicylate hydroxylase. Clin Chem 1984;30(9):1549-51.

[86] Chang BV, Chang SW, Yuan SY. Anaerobic degradation of polycyclic aromatic hydrocarbons in sludge. Adv Environ Res 2003;7(3):623-8.

[87] Meckenstock RU, Annweiler E, Michaelis W, Richnow HH, Schink B. Anaerobic naphthalene degradation by a sulfate-reducing enrichment culture. Appl Environ Microbiol 2000;66(7):2743-7.

[88] Fuchs G, Altenschmidt U, Oswald B. Purification and characterization of benzoate-coenzyme A ligase and 2-aminobenzoatecoenzyme A ligases from a denitrifying Pseudomonas sp. J Bacteriol 1991;173(17):5494-501.

[89] Lack A, Fuchs G. Evidence that phenol phosphorylation to phenylphosphate is the first step in anaerobic phenol metabolism in denitrifying Pseudomonas sp. Arch Microbiol 1994;161:132-9.

[90] Fuchs G, Schühle K, Gescher J, Feil U, Paul M, Jahn M, et al. Benzoate-coenzyme A ligase from Thauera aromatica: an enzyme acting in anaerobic and aerobic pathways. $J$ Bacteriol 2003;185(16):4920-9.

[91] Zhang X, Young LY. Carboxylation as an initial reaction in the anaerobic metabolism of naphthalene and phenanthrene by sulfidogenic consortia. Appl Environ Microbiol 1997;63(12):4759-64.

[92] Karthikeyan R, Bhandari A. An Anaerobic biotransformation of aromatic and polycyclic aromatic hydrocarbons in soil microcosms: a review. J Hazard Subs Res 2001;3:1-19.

[93] Harwood CS, Gibson J. Shedding light on anaerobic benzene ring degradation: a process unique to prokaryotes? J Bacteriol 1997;179(2):301-9.

[94] http://umbbd.ahc.umn.edu/.

[95] Alcade M, Bulter T, Arnold FH. Colorimetric assays for biodegradation of polycyclic aromatic hydrocarbons by fungal laccases. J Biomol Screen 2002;7(6):547-53.

[96] Pickard MA, Roman R, Tinoco R, Vazquez-Duhalt R. Polycyclic aromatic hydrocarbon metabolism by white rot fungi and oxidation by Coriolopsis gallica UAMH 8260 laccase. Appl Environ Microbiol 1999;65(9):3805-9.

[97] Collins PJ, Kotterman MJJ, Field JA, Dobson ADW. Oxidation of anthracene and benzo[a]pyrene by laccases from Trametes versicolor. Appl Environ Microbiol 1996;62:4563-7.

[98] Vazquez-Duhalt R, Westlake DWS, Fedorak PM. Lignin peroxidase oxidation of aromatic compounds in systems containing aromatic solvents. Appl Environ Microbiol 1994;60:459-66.
[99] Bogan B, Lamar RT. Polycyclic aromatic hydrocarbon-degrading capabilities of Phanerochaete laevis HHB-1625 and its extracellular ligninolytic enzymes. Appl Environ Microbiol 1996;62:1597603

[100] Johannes C, Majcherczyk A, Huttermann A. Degradation of anthracene by laccases of Trametes versicolor in the presence of different mediators. Appl Microbiol Biotechnol 1996;46:313-7.

[101] Majcherczyk A, Johannes C, Huttermann A. Oxidation of polycyclic aromatic hydrocarbons (PAH) by laccase of Trametes versicolor. Enzyme Microbiol Technol 1998;22:335-41.

[102] d'Acunzo F, Galli C, Masci B. Oxidation of phenols by laccasemediator systems. Eur J Biochem 2002;269(12):5330-5.

[103] Khasin A, Alchanati I, Shoham Y. Purification and characterization of xylanase from Bacillus stearothermophilus T-6. Appl Environ Microbiol 1993;59:1725-30

[104] Teixeira Duarte MC, Cristina da Silva E, Menezes de Bulhoes Gomes I, Nunes Ponezi A, Princi Portugal E, Roberto Vicente J, et al. Xylanhydrolyzing enzyme system from Bacillus pumilus CBMAI 0008 and its effects on Eucalyptus grandis kraft pulp for pulp bleaching improvement. Biores Technol 2003;88(1):9-15.

[105] Bocchini DA, Damiano VB, Gomes E, Da Silva R. Effect of Bacillus circulans D1 thermostable xylanase on biobleaching of eucalyptus kraft pulp. Appl Biochem Biotechnol 2003;106(13):393-402.

[106] Kansoh AL, Nagieb ZA. Xylanase and Mannanase enzymes from Streptomyces galbus NR and their use in biobleaching of softwood kraft pulp. Antonie van Leeuwenhoek 2004;85(2):103-14.

[107] Beg QK, Kapoor M, Mahajan L, Hoondal GS. Microbial xylanases and their industrial applications: a review. Appl Microbiol Biotechnol 2001;56(3-4):326-38.

[108] Cripps C, Bumpus JA, Aust SD. Biodegradation of azo and heterocyclic dyes by Phanerochaete chrysosporium. Appl Environ Microbiol 1990;56:1114-8.

[109] Capalash N, Sharma P. Biodegradation of textile azo-dyes by Phane rochaete chrysosporium. World J Microbiol Biotechnol 1992;8:309-12.

[110] Chao WL, Lee SL. Decolourisation of azo dyes by three whiterot fungi: influence of carbon source. World J Microbiol Biotechnol 1994;10:556-9.

[111] Wu F, Ozaki H, Terashima Y, Imada T, Ohkouchi T. Activities of ligninolytic enzymes of the white-rot fungus Phanerochaete chrysosporium and its recalcitrant substances degradability. Water Sci Technol 1996;34:69-78.

[112] Fu Y, Viraraghavan T. Fungal decolorization of dye wastewaters: a review. Biores Technol 2001;79:251-62.

[113] Toh Y-C, Yen JJL, Obbard JP, Ting Y-P. Decolourisation of azo dyes by white-rot fungi (WRF) isolated in Singapore. Enzyme Microbiol Technol 2003;33:569-75.

[114] Russ R, Rau J, Stolz A. The function of cytoplasmic flavin reductases in the reduction of azo dyes by bacteria. Appl Environ Microbiol 2000;66:1429-34

[115] Chung KT, Fulk GE, Egan M. Reduction of azo dyes by intestinal anaerobes. Appl Environ Microbiol 1978;35:558-62.

[116] Kudlich M, Keck A, Klein J, Stolz A. Localization of the enzyme system involved in anaerobic reduction of azo dyes by Sphingomonas sp. strain BN6 and effect of artificial redox mediators on the rate of azo dye reduction. Appl Environ Microbiol 1997;63:3691-4.

[117] Silver S. Genes for all metals - a bacterial view of the Periodic Table: the 1996 Thom Award Lecture. J Ind Microbiol Biotechnol 1998;20(10):1-12.

[118] Rouch DA, Lee BTD, Morby AP. Understanding cellular responses to toxic agents: a model for mechanism choice in bacterial metal resistance. J Ind Microbiol 1995;14:132-41.

[119] Tsivkovskii R, Eisses JF, Kaplan JH, Lutsenko S. Functional properties of the copper-transporting ATPase ATP7B. (The Wilson's disease protein) expressed in insect cells. J Biol Chem 2002;277(2):976-83.

[120] Cobine PA, George GN, Jones CE, Wickramasinghe WA, Solioz M, Dameron CT. Copper transfer from the $\mathrm{Cu}(\mathrm{I})$ chaperone, $\mathrm{CopZ}$, to the repressor, $\mathrm{Zn}(\mathrm{II}) \mathrm{CopY}$ : metal coordination environments and protein interactions. Biochemistry 2002;41(18):5822-9. 
[121] Silver S, Phung LT. Bacterial heavy metal resistance: new surprises. Ann Rev Microbiol 1996;50:753-89.

[122] Rapisarda VA, Motelongo LR, Farias RN, Massa EM. Characterization of an NADH-linked cupric reductase activity from the Escherichia coli respiratory chain. Arch Biochem Biophys 1999;370(2):143-50.

[123] Nascimento AMA, Chartone-Souza E. Operon mer: bacterial resistance to mercury and potential for bioremediation of contaminated environments. Genet Mol Res 2003;2(1):92-101.

[124] Misra TK. Bacterial resistances to inorganic mercury salts and organomercurials. Plasmid 1992;25:4-16.

[125] Brown NL, Shih Y-C, Leang C, Glendinning KJ, Hobman JL, Wilson JR. Mercury transport and resistance. Biochem Soc Trans 2001;30:715-8.

[126] Nkhalambayausi-Chirwa EM, Wang YT. Simultaneous chromium(VI) reduction and phenol degradation in a fixed-film coculture bioreactor: reactor performance. Water Res 2001;35(8):1921-32.

[127] Cervantes C, Campos-Garcia J, Devars S, Gutierrez-Corona S, LozaTavera H, Torres-Guzman JC, et al. Interactions of chromium with microorganisms and plants. FEMS Microbiol Rev 2001;25:335-47.

[128] Park CH, Keyhan M, Wielinga B, Fendorf S, Matin A. Purification to homogeneity and characterization of a novel Pseudomonas putida chromate reductase. Appl Environ Microbiol 2000;66(5):1788-95.

[129] Michel C, Brugna M, Aubert C, Bernadac A, Bruschi M. Enzymatic reduction of chromate: comparative studies using sulphate reducing bacteria. Key role of polyheme cytochromes and hydrogenases. Appl Microbiol Biotechnol 2001;55:95-100.

[130] Chardin B, Giudici-Orticoni M-T, De Luca G, Guigliarelli B, Bruschi $\mathrm{M}$. Hydrogenases in sulfate-reducing bacteria function as chromium reductase. Appl Microbiol Biotechnol 2003;63(3):315-21.

[131] Beinert H. A tribute to sulphur. Eur J Biochem 2000;267:5657-64.

[132] Nicolet Y, Cavazza C, Fontecilla-Camps JC. Fe-only hydrogenases: structure, function, and evolution. J Inorg Biochem 2002;91:1-8.

[133] Volbeda A, Charon MH, Piras C, Hatchikian EC, Frey M, FontecillaCamps JC. Crystal structure of the nickel-iron hydrogenase from Desulfovibrio gigas. Nature 1995;373:580-7.

[134] Kurkin S, Meuer J, Koch J, Hedderich R, Albrecht SPJ. The membrane-bound [NiFe]-hydrogenase (Ech) from Methanosarcina barkeri: unusual properties of the iron-sulphur clusters. Eur J Biochem 2002;269(24):6101-11.

[135] Fontecilla-Camps JC. The active site of Ni-Fe hydrogenases: model chemistry and crystallographic results. J Biol Inorg Chem 1996;1:91-8.

[136] Frey M. Nickel-iron hydrogenases: structural and functional properties. Struct Bond 1998;90:97-126.

[137] Garcin E, Montet Y, Volbeda A, Hatchikian C, Frey M, FontecillaCamps JC. Structural bases for the catalytic mechanism of $[\mathrm{NiFe}]$ hydrogenases. Biochem Soc Trans 1998;26:396-401.

[138] Odom JM, Peck HD. Hydrogenase, electron-transfer proteins, and energy coupling in the sulfate-reducing bacteria Desulfovibrio. Ann Rev Microbiol 1984;38:551-92.

[139] Lloyd JR, Yong P, Macaskie L. Enzymatic recovery of elemental palladium by using sulfate-reducing bacteria. Appl Environ Microbiol 1998;64(11):4607-9.

[140] de Vargas I, Macaskie LE, Guibal E. Biosorption of palladium and platinum by sulphate-reducing bacteria. J Chem Tech Biotech 2004;79(1):49-56.

[141] Ortiz-Bernad I, Anderson RT, Vrionis HA, Lovley DR. Vanadium respiration by Geobacter metallireducens: novel strategy for in situ removal of vanadium from groundwater. Appl Environ Microbiol 2004;70(5):3091-5.

[142] Lovley DR, Roden EE, Phillips EJP, Woodward JC. Enzymatic iron and uranium reduction by sulphate-reducing bacteria. Mar Geol 1993;113:41-53.

[143] Lovley DR. Dissimilatory Fe(III) and Mn(IV) reduction. Microbiol Rev 1991;55:259-87.

[144] Coppi MV, O'Neil RA, Lovley DR. Identification of an uptake hydrogenase required for hydrogen-dependent reduction of $\mathrm{Fe}(\mathrm{III})$ and other electron acceptors by Geobacter sulfurreducens. J Bacteriol 2004;186(10):3022-8.
[145] Lloyd JR, Sole VA, Van Praagh CVG, Lovley DR. Enzymatic and $\mathrm{Fe}(\mathrm{II})$-mediated reduction of technetium by $\mathrm{Fe}(\mathrm{III})$-reducing bacteria. Appl Environ Microbiol 2000;66:3743-9.

[146] Lloyd JR, Ridley J, Khizniak T, Lyalikova NN, Macaskie LE. Reduction of technetium by Desulfovibrio desulfuricans: biocatalyst characterisation and use in a flow-through bioreactor. Appl Environ Microbiol 1999;65:2691-6.

[147] Lloyd JR, Macaskie LE. Bacterial reduction of technetium. Miner Process Extr Metall Rev 1998;19:265-75.

[148] French CE, Nicklin S, Bruce NC. Aerobic degradation of 2,4,6trinitrotoluene by Enterobacter cloacae $\mathrm{PB} 2$ and by pentaerythritol tetranitrate reductase. Appl Environ Microbiol 1998;64(8):2864-8.

[149] Kakutani T, Watanabe H, Arima K, Beppu T. Purification and properties of a copper-containing nitrite reductase from a denitrifying bacterium, Alcaligenes faecalis strain S-6. J Biochem 1981;89(2):45361.

[150] Pak JW, Knoke KL, Noguera DR, Fox BG, Chambliss GH. Transformation of 2,4,6-trinitrotoluene by purified xenobiotic reductase B from Pseudomonas fluorescens 1-C. Appl Environ Microbiol 2000;66(11):4742-50.

[151] Bothe H, Jost G, Schloter M, Ward BB, Witzel KP. Molecular analysis of ammonia oxidation and denitrification in natural environments. FEMS Microbiol Rev 2000;24:673-90.

[152] Averill BA. Dissimilatory nitrite and nitric oxide reductase. Chem Rev 1996;96:2951-64.

[153] Watrous MM, Clark S, Kutty R, Huang S, Rudolph FB, Hughes $\mathrm{JB}$, et al. 2,4,6-Trinitrotoluene reduction by an Fe-only hydrogenase in Clostridium acetobutylicum. Appl Environ Microbiol 2003;69(3):1542-7.

[154] Schippers A, Sand W. Bacterial leaching of metal sulfides proceeds by two indirect mechanisms via thiosulfate or via polysulfides and sulfur. Appl Environ Microbiol 1999;65(1):319-21.

[155] Kletzin A. Coupled enzymatic production of sulfite, thiosulphate, and hydrogen sulphide from sulfur: purification and properties of a sulfur oxygenase reductase from the facultative anaerobic archaebacterium Desulfurolobus ambivalens. J Bacteriol 1989;171(3):1638-43.

[156] Urich T, Bandeiras TM, Leal SS, Rachel R, Albrecht T, Zimmerman P, et al. The sulphur oxygenase reductase from Acidianus ambivalens is a multimeric protein containing a lowpotential mononuclear non-haem iron centre. Biochem J 2004;381(1):137-46.

[157] Stemmer WPC. Rapid evolution of a protein in vitro by DNA shuffling. Nature 1994;370:389-91.

[158] Zhao H, Giver L, Shao Z, Affholter JA, Arnold F. Molecular evolution by staggered extension process in vitro recombination. Nat Biotechnol 1998;16:258-61.

[159] Okuta A, Ohnishi K, Harayama S. PCR isolation of catechol 2,3dioxygenase gene fragments from environmental samples and their assembly into functional genes. Gene 1998;212:221-8.

[160] Lowry OH, Rosbrough NJ, Farr AL, Randall RJ. Protein measurement with the folin phenol reagent. J Biol Chem 1951;193:265-75.

[161] Bradford MM. A rapid and sensitive for the quantitation of microgram quantitites of protein utilizing the principle of protein-dye binding. Anal Biochem 1976;72:248-54.

[162] Ogunseitan OA. Protein method for investigating mercuric reductase gene expression in aquatic environment. Appl Environ Microbiol 1998;64(2):695-702.

[163] Korn E. Isolation and characterization of a lipase enzyme from normal rat heart. J Biol Chem 1954;2:1-13.

[164] Hattenberger M, Mascher F, Kalcher K, Marth E. Improved method for the fluorimetric detection of $\beta$-D-galactosidase in water. Int J Hyg Environ Health 2001;203:281-7.

[165] Goel R, Mino T, Satoh H, Matsuo T. Enzyme activities under anaerobic and aerobic conditions in activated sludge sequencing batch reactor. Water Res 1998;32:2081-8.

[166] Bizily SP, Kim T, Kandasamy MK, Meagher RB. Subcellular targeting of methylmercury lyase enhances its specific activity for organic mercury detoxification in plants. Plant Physiol 2003;131:46371. 
[167] Gibson J, Geissler JF, Harwood CS. Purification and properties of benzoate-coenzyme A ligase, a Rhodopseudomonas palustris enzyme involved in the anaerobic degradation of benzoate. $\mathrm{J}$ Bacteriol 1988;170(4):1709-14.

[168] Hernandez PH, Gilette R, Mazel P. Studies on the mechanism of action of mammalian hepatic azoreductase. II. The effect of pheno- barbital and 3-methyl-cholanthrene on carbon monoxide sensitive and insensitive azoreductase activity. Biochem Pharmacol 1967;16:187788.

[169] Woo G-J, Wasserfallen A, Wolfe RS. Methyl viologen hydrogenase II, a new member of the hydrogenase family from Methanobacterium thermoautotrophicum AH. J Bacteriol 1993;175(18):5970-7. 